\title{
Resilience as a framework for analyzing the adaptation of mountain summer pasture systems to climate change
}

\author{
Baptiste Nettier $^{1,2,3}$, Laurent Dobremez $^{1}$, Sandra Lavorel ${ }^{4}$ and Gilles Brunschwig. $^{2,3}$
}

\begin{abstract}
Social-ecological resilience is defined by Brian Walker and colleagues as "the capacity of a social-ecological system (SES) to absorb disturbances and reorganize while undergoing change so as to continue to retain essentially the same function, structure, feedbacks, and therefore identity." It is an increasingly widespread concept whose success depends, among other things, on the promise of its rapid transfer from science into practice and its operational character for the sustainable management of SESs. However, tangible examples of management methods based on resilience remain limited in the scientific literature. Here, we test the resilience management framework proposed by Brian Walker and David Salt by applying it to the case of mountain summer pastures in the French Alps, which are complex SESs in which human and ecological dimensions are closely linked and subject to substantial perturbations due to climate change. Three steps were implemented: (1) building a conceptual model based on expert knowledge of the functioning of summer pastures; (2) building, from the model, a template for summer pasture resilience analysis; and (3) testing the operational character of the model and the template for two pairs of contrasting cases. This heuristic tool enables understanding the ways in which farmers and herders manage the resilience of their system but does not aim to quantify resilience. The method developed, together with the resilience concept, provide insights into the functioning of summer pastures from both biophysical and management perspectives. The modeling process constitutes a learning process, which will support the implementation of adaptive management. We identified three critical points for making the method truly operational: basing modeling on an equal consideration of social and ecological dimensions, defining the boundaries of the modeled system based on the social dimension, and selecting a scale of analysis coherent with the type of development actions to be implemented.
\end{abstract}

Key Words: adaptation to climate change; participatory modeling; social-ecological resilience; summer mountain pastures

\section{INTRODUCTION}

Using the concept of resilience to manage social-ecological systems

The concept of social-ecological resilience, understood as "the capacity of a social-ecological system (SES) to absorb disturbances and reorganize while undergoing change so as to continue to retain essentially the same function, structure, feedbacks, and therefore identity" (Walker et al. 2004), is being increasingly used to address issues of SES management (Walker and Salt 2006). Among the concepts linked to social-ecological resilience, the panarchy concept (Gunderson and Holling 2002) can be summarized as two principles: (1) SESs constantly evolve over time, according to the disturbances that cause them to adapt or transform; and (2) developing adaptability at one level could necessitate a transformation at another level.

For many authors, resilience theory offers useful insights into resource management (Allen et al. 2005, Anderies et al. 2006, Soane et al. 2012, Carlisle 2014), and resilience thinking is a way to achieve sustainability (Brand 2005, Perrings 2006, Domptail et al. 2013). The promise of its operational character and the possible rapid transfer of scientific concepts into practice largely explain the success of the concept.

However, most published studies do not go beyond the analysis of the functioning of a system at a given time or involve a retrospective analysis of system transformations. Many case studies in different schools and disciplines have qualified and described the characteristics of SESs and their resilience mechanisms and have aimed to identify their conditions for adaptability (defined as "the capacity of actors in the system to influence resilience") and transformability (defined as "the capacity to create a fundamentally new system when ecological, economic, or social structures make the existing system untenable"; Folke et al. 2004, Walker et al. 2004, 2006). SESs research thus covers a range of different issues such as irrigation (Cifdaloz et al. 2010), fisheries (Camp et al. 2015), or rangelands (Reid et al. 2014) and focuses on disturbances as diverse as water pollution (Carpenter et al. 2001), coastal disasters (Adger et al. 2005), climate change (Smit and Wandel 2006), or global change (Anderies et al. 2013). However, with a few exceptions, listed in particular by Miller et al. (2010) and Walker and Salt (2006, 2012), scientific articles that attempt to make tangible management recommendations remain limited (e.g., see Cabell and Oelofse 2012).

Early research work aiming to assess SES resilience levels (Allen et al. 2005, Cumming et al. 2005) paved the way for discussions about shifting from the concept of resilience toward practice. It was observed that a system's resilience is relative and that assessing the resilience of a system requires, as a first step, a careful description of the system's boundaries and the properties to be preserved, as well as the disturbances of interest, i.e., detailing the "resilience of what to what" (Carpenter et al. 2001). Several of these papers also conclude that it is difficult to define direct quantitative indicators and instead suggest identifying "surrogates" in relation to aspects conferring resilience to a system (Bennett et al. 2005, Carpenter et al. 2005, Darnhofer et al. 2010b,

${ }^{1}$ Université Grenoble Alpes, Irstea, UR DTGR, BP 76, F-38402 St-Martin-d'Hères, France, ${ }^{2}$ Université Clermont Auvergne, VetAgro Sup, 
Carlisle 2014). Indeed, identifying which properties confer resilience to a system seems more operational and easier to adopt for actors whose objective is not to measure but rather to achieve resilience (see also Quinlan et al. 2016).

Empowered by these insights, and in their attempt to operationalize the concept, Walker and Salt (2006, 2012) published two popular science books. The first is a presentation of resilience and the interest of this concept (Walker and Salt 2006), and the second is a method for resilience practice (Walker and Salt 2012) that encompasses and completes the works of Walker et al. (2009) and of the Resilience Alliance (2007, 2010). In this second book, Walker and Salt (2012) propose a list of generic criteria that confer resilience to SESs. This method must still be tested in different real cases to assess its operational character in diverse situations.

\section{Analyzing the operational character of resilience through the case of mountain summer pastures}

Mountain summer pastures can be defined as permanent grasslands used specifically for grazing in summer and whose location does not make it possible to bring livestock back to the farm every day (Flamant et al. 1999). They are used by many livestock farmers in mountain regions and surrounding plains and cover a wide variety of sizes, configurations, elevations, and altitudinal zones, mainly in the subalpine and alpine belts. Summer pastures are often used collectively by several farmers and, depending on the case, are managed by one of the farmers or by one or several hired herders (Guéringer et al. 2009). Summer pastures are also multipurpose areas (tourism, hunting, logging, etc.) with very rich biodiversity resulting from several thousand years of pastoral use (Walsh et al. 2014) that contribute to landscapes of great cultural value (Soane et al. 2012). Summer pastures are thus a typical example of an SES with closely linked human and ecological dimensions.

Climate change creates strong perturbations to summer pasture SESs, which are inherently highly exposed (IPCC 2014), and challenges their ability to adapt. Climate change leads to two challenges in two different time frames.

In the short term of annual management, climate change translates as an increase in interannual climate variability (IPCC 2013) and an increase in the frequency and intensity of extreme events, particularly summer droughts and extreme heat (Schär et al. 2004, IPCC 2012). In the 2000s, the Alps experienced a series of exceptionally serious droughts that will likely become the norm by the end of the 21st century (Calanca 2007). These droughts forced farmers and herders to modify their practices, first, in the pastures (Nettier et al. 2011) by forcing herds to consume less palatable vegetation, by exploring less accessible sectors of pastures, or by preserving from herds the less drought-sensitive vegetation as long as possible, and second, by adjusting management, including stocking rates, on both farms and summer pastures (Nettier et al. 2010, Rigolot et al. 2014) to continue to ensure fodder supply to the herds and to avoid harming the vegetation.

In the long term, climate change is expected to initiate a change in the vegetation found in summer pastures (Engler et al. 2011), with major uncertainties as to future trajectories (Scherrer and Körner 2010, Gottfried et al. 2012, IPCC 2014). These uncertainties justify acting today, in particular, via pastoral practices because they can have stronger and swifter effects on vegetation than does climate (and their effects are better known; Benot et al. 2014). The challenge for summer pastures is therefore to use pastoral management to ensure their resilience to climate disturbances to maintain their long-term functions, i.e., their capacity to provide fodder to herds in summer and also their multipurpose character.

In the French Alps, our study area, extension officers use analytical and management-support tools (Jouglet 1999, Bornard et al. 2007, CERPAM and Parc national des Ecrins 2006) aimed at: (1) quantifying the average resources present on summer pastures (Daget and Poissonet 1971, 1972, Bernard-Brunet and Bornard 2004), and (2) understanding the pasture management strategies used by herders in an average year (Savini et al. 1995, 2010). However, these tools are not adequate to manage adaptation to climate change. They do not make it possible to take into account interannual variations in biomass production; they ignore the vegetation development stage appropriate for grazing or the capacity of herders to have herds consume plants that are a priori not palatable (Cruz et al. 2002, Guérin et al. 2007). It is difficult to use these tools to identify the adjustments required for summer pastures or summer pasture-farm interactions, i.e., the "summer pasture-farms system" (Nettier et al. 2015), and they do not take into account the dynamic character of summer pastures (both vegetation and the farms using the pastures are considered to be stable).

Here, our goal is to assess the operational character of the socialecological resilience concept for management by studying climate change adaptation issues on summer pastures. For this, we propose to use the methodological framework developed by Walker and Salt (2012) to manage the resilience of SESs, adjusting it to the specific characteristics of the summer pasture SES. Should the outcome of this examination be positive, this work could then be used to improve current frameworks for assessing summer pasture management.

\section{METHODS}

Walker and Salt (2012) propose a three-stage method to "practice resilience" consisting of: (1) describing the system through conceptual modeling, (2) evaluating the system's resilience, and (3) managing the system's resilience (Fig. 1).

Fig. 1. Methodology developed for practicing resilience, adapted from the work of Walker and Salt (2012).

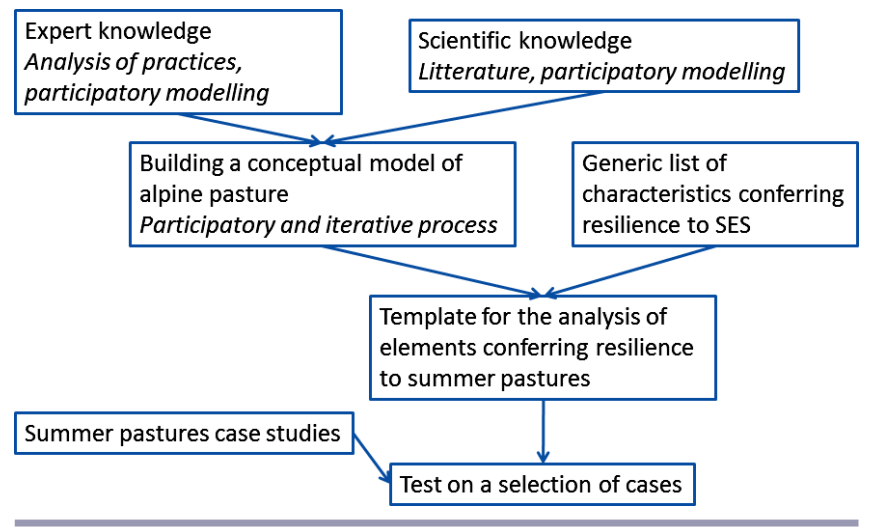




\section{Describing the system using conceptual modeling}

The aim of this description is to understand the way in which the system functions by identifying the different scales of interest, the actors, the system's functions and properties that are to be maintained (resilience of what), the disturbances threatening the system (resilience to what) (Carpenter et al. 2001), and the drivers that affect the system. Participatory methods are recommended for this type of modeling approach (Walker et al. 2002, Darnhofer et al. 2010a, Walker and Salt 2012) because it is important to involve a wide variety of actors to compare different viewpoints (Brown 2010) and to combine complementary knowledge (mainly "scientific" and "local" or "empirical" knowledge; Reed 2008). Walker and Salt (2012) also propose an iterative approach to reduce progressively the model's complexity and select only the most significant drivers to maximize operationality and uptake. Following these recommendations, we built a conceptual model of the functioning of a summer pasture. Our aim was to build a qualitative model that could be used as a basis for understanding the system and reasoning its management. Given that our primary aim was the production of a diagnostic framework, we did not develop an operational, quantitative tool per se, but this could be a future development (see Discussion).

To build this model, we worked with the Sentinel summer pastures program (Dobremez et al. 2014), which is an informal structure and a forum for exchange on questions of climate change impact on summer pastures and on adaptation. This network links a diversity of stakeholders from the French Alps who are concerned with both pastoral and multipurpose functions of alpine pastures, including pastoral extension officers, managers of protected areas, researchers in ecology and agronomy working in the region, and also farmers and herders. It is built around a monitoring system comprising a sample of 24 summer pastures representing diverse geographic and socioeconomic contexts. We used an iterative process to combine: (1) an analysis of the tools used by extension officers and the way they are used in the field, which may differ from the initial objective and reveal insights into the functioning of the system (Gross et al. 2011); (2) 10 working sessions between April 2013 and February 2015 with 13 experts (Table 1, among which are three of the authors of this paper) involved for part or all of the process (Fig. 2); (3) a selection of scientific research to confirm certain hypotheses regarding ecological functioning (Jonas et al. 2008, Choler 2015) or to derive inspiration from management models focusing on the management of climate variability (Moulin et al. 2001); and (4) a panel of diversified case studies among the sample of cases from the Sentinel summer pastures program (sheep and cattle, local and transhumant farmers, individual and collective organizations) that were used as examples for proof of concept. The conceptual model is mainly based on scientific and technical knowledge, but extension officers also tried to report empirical knowledge learned from their exchanges with herders.

Despite the diversity of stakeholders involved, during the modeling process, we chose to consider only the pastoral dimensions of summer pastures. Indeed, stakeholders stated that maintaining pastoral functions was a prerequisite to the conservation of multipurpose functions. Also, the model was designed focusing on climatic perturbations, which was the thematic of interest of the group. Thus, considering the "resilience of what to what" question, we focused on the resilience of the pastoral function of summer pastures, defined as the capacity of pastures to ensure the herds' feeding requirements during the summer season to climatic perturbations, including climatic hazards (in priority) and long-term climate change. To structure our conceptual model, we referred to research on livestock farming systems (Gibon et al. 1999), which incorporates previous work on the modeling of summer pasture functioning (Savini et al. 1995, 2010) and supports the analysis of management strategies. Our interest was in the "human-herd-resource" triad described by this research, i.e., the way farmers and herders manage the fit between the herd's needs and available resources. We considered that a livestock farming system comprises two interacting subsystems: (1) a decision system, indicating how farmers and herders manage the fit between the herd's needs and the food resources provided by the vegetation; and (2) a biophysical system, comprising soil-plant-animal-climate interactions. Like Tittonell (2014), we considered that the biophysical system represents the ecological dimension of a livestock farming SES, and we considered the management system to represent the system's social dimension.

Table 1. Stakeholders involved in the participatory modeling process (initials correspond to experts' names).

\begin{tabular}{ll}
\hline \hline $\begin{array}{l}\text { Expert } \\
\text { code }\end{array}$ & Status \\
\hline AS & Extension officer (pastoral services, southern Alps) \\
JV & Extension officer (pastoral services, northern Alps) \\
LG & Extension officer (pastoral services, southern Alps ) \\
SV & Extension officer (pastoral services, southern Alps ) \\
CD & Botanist (National Park) \\
CS & Responsible for measurement protocols (National Park) \\
MD & Responsible for agriculture theme (National Park) \\
VA & Responsible for natural environment (National Park) \\
BN & Scientist: agronomy \\
LD & Scientist: agronomy \\
PC & Scientist: ecology, ecoclimatology \\
SL & Scientist: ecology \\
OS & Phytoecologist \\
\hline
\end{tabular}

We then formulated the general structure of the pastoral SES that we aimed to model (Fig. 3, inspired by Collins et al. 2011). On the ecological dimension, climate directly influences both herd and vegetation development. The herd's behavior also affects vegetation. In pastoral systems, management is made nearly exclusively through direct practices on the herd (in particular, grazing management), and direct benefits derived from the system are exclusively animal production. However, management is also a result of the way farmers and shepherds perceive every element of the environment: climate as well as herd and vegetation conditions.

Among the many formalisms used in participatory modeling approaches (Lynam et al. 2007), we chose two different formalisms to model the functioning of the biophysical system in the two time frames of interest: the annual scale at which the increase in the number of climatic hazards needs to be managed, and the longer term for vegetation changes in response to combined changes in pastoral practices and climate change. For the annual scale, we used the formalism of causal maps (cognitive maps) detailing the causal links between weather parameters or pastoral practices and vegetation growth and phenology 
Fig. 2. Sequences of the participatory modeling process and experts involved. Experts indicated by initials (see Table 1).

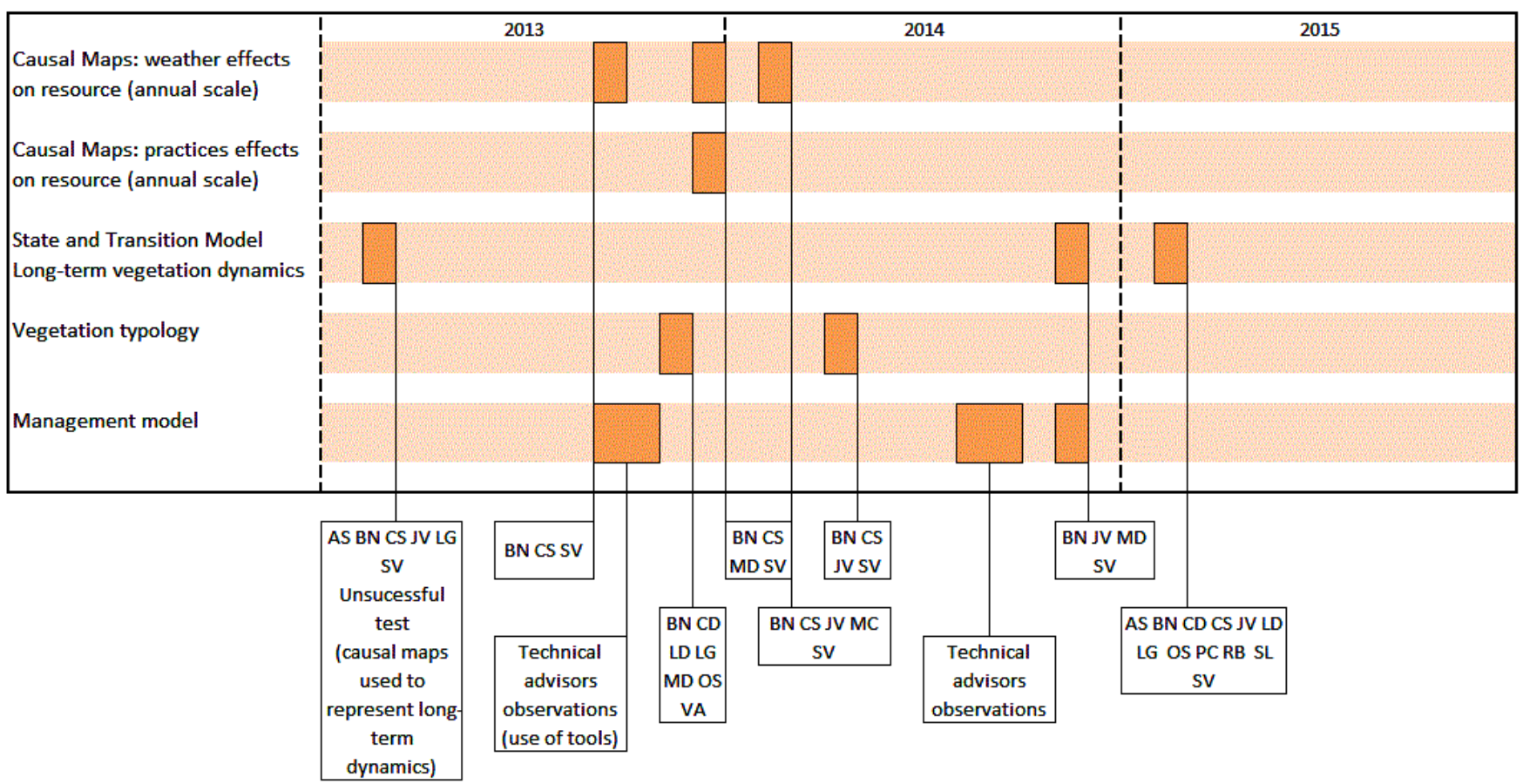

Fig. 3. General structure of the modeled pastoral socialecological system.

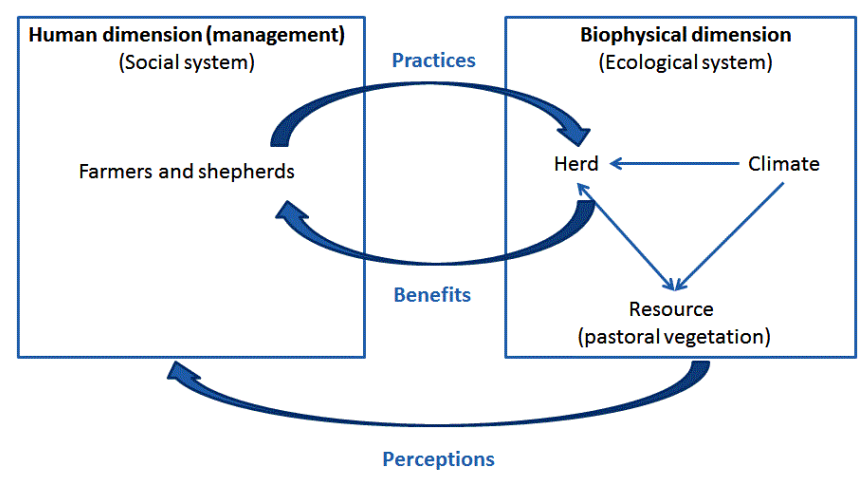

(Gouttenoire et al. 2010). From these causal maps, we identified factors of vegetation sensitivity to weather events and to pastoral practices, e.g., sensitivity of phenology to temperature or sensitivity of production to drought. For the long term, we built a state and transition model: this type of representation is well suited to articulate shifts between vegetation types according to practices and climate conditions (Westoby et al. 1989, Mathevet et al. 2007, McIntyre and Lavorel 2007). The management model was built to represent the ways that different hazards are managed at different management time scales (from daily to pluri-annual). Based on this structure, we were able to define precise pastoral functions in the grazing schedule that can be associated with agronomic properties of the vegetation. Combined with different biophysical contexts, these characteristics were the basis for a
Fig. 4. Full architecture of the summer pasture model.

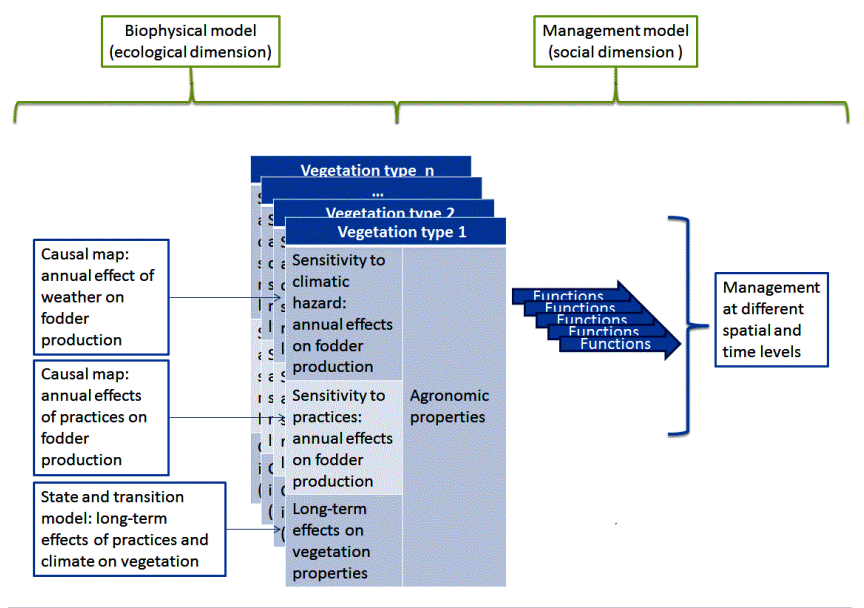

vegetation typology depicting the potential functions of different vegetation types at different management scales, as well as their sensitivity to climate hazards and pastoral practices (Fig. 4).

Building a template to identify and analyze elements conferring resilience to summer pasture social-ecological systems

Our aim was not to quantify resilience but rather to identify the characteristics that do or do not confer resilience to summer pasture on the ground and to produce a heuristic tool to analyze what confers the resilience of a given summer pasture. To reach this goal, we decided to build a template providing a checklist of elements conferring resilience to summer pastures. Walker and Salt (2012) propose a complete generic list of characteristics 
Table 2. Generic criteria for conferring resilience to a social-ecological system, according to Walker and Salt (2012).

\begin{tabular}{|c|c|}
\hline Criterion & Description \\
\hline Diversity & $\begin{array}{l}\text { Diversity in all forms: biological, landscape, social, and economic. Major source of future options and a system's capacity to } \\
\text { respond to change and disturbance in different ways. Two types of diversity: functional and response diversity }\end{array}$ \\
\hline Openness & $\begin{array}{l}\text { Refers to the ease with which people, ideas, and species can move into and out of the system. Systems that are too open or too } \\
\text { closed can have reduced resilience }\end{array}$ \\
\hline Reserves & $\begin{array}{l}\text { Having more in reserve means greater resilience: natural reserves (habitat patches, seeds, water supply, grazing area, etc.), economic } \\
\text { reserves (levels of savings), or social reserves (knowledge). Closely linked to the notion of capital (natural capital, built capital, } \\
\text { human capital, financial capital) }\end{array}$ \\
\hline $\begin{array}{l}\text { Tightness of } \\
\text { feedbacks }\end{array}$ & $\begin{array}{l}\text { Tight and strong feedbacks allow the detection of thresholds before they are crossed. Ecological feedbacks and the capacity of } \\
\text { actors to detect a disturbance and react rapidly are closely linked to the actors' abilities to learn about the system }\end{array}$ \\
\hline Modularity & $\begin{array}{l}\text { A fully connected system will rapidly transmit all shocks through the whole system (e.g., disease, wildfire, bad management } \\
\text { practices). In a system with loosely connected subcomponents, parts of the system are able to reorganize in response to changes } \\
\text { elsewhere in the system in time to avoid disaster }\end{array}$ \\
\hline Social capital & $\begin{array}{l}\text { Three intertwined attributes are important for the coping capacity of a community: (1) leadership, considered as a process, with } \\
\text { different kinds of leadership for different circumstances; (2) interconnected social networks; and (3) trust. Determines the } \\
\text { community's empowerment, i.e., its capacity to act in making its own choices }\end{array}$ \\
\hline
\end{tabular}

conferring resilience to SESs (Table 2). To design the template, we compared Walker and Salt's list with the summer pasture model and identified tangible elements from the pasture model that could match generic resilience criteria and make them more concrete. Such elements represent our analytical framework, to be applied to summer pasture cases on the ground. We organized this template with concern for its operational use and followed the stakeholders' points of view described in the model. Therefore, we distributed the different elements in three columns corresponding to the human-herd-resource triad (Gibon et al. 1999): the first column comprises social elements such as work, knowledge, or social networks; the second column presents elements related to animal behavior and characteristics and zootechnical management; the third column elements relate to vegetation as used through management (such as functional characteristics or spatial pattern). The different rows of the template correspond to the different scales identified in the modeling process. Thus, to design this table, we asked for each cell, representing a single theme (column) at a given management scale (row), how Walker and Salt's (2012) generic criteria could be translated into concrete criteria for the conceptual model (Table 3).

\section{Managing the resilience of summer pasture social-ecological systems}

In this last stage, we tested the analytical framework for four case studies of summer pastures monitored in the Sentinel summer pasture program to test its relevance and to verify that it can generate ideas conducive to preserving or improving summer pasture resilience. We chose to analyze two pairs of contrasting cases. The contrast of situations within each pair makes it possible to illustrate how the template can be used to better analyze certain aspects that are rarely taken into account in the functioning of summer pastures but that nevertheless appear essential for adaptation to climate change. For this, we focused on two key themes addressed in the case comparison: (1) for the first pair of summer pastures (Dar and Cro cases, names anonymized), we focused on the use and management of vegetation diversity, which is at the heart of many integrated natural resource management problems; (2) for the second pair (Sur and Pon cases), we focused on the management of the system by the group of actors (livestock farmers and herders) because the collective nature of summer pasture governance (Eychenne and Lazaro 2014, Reid et al. 2014) is an unusual specificity among farming systems in Europe that was not taken into account in a previous summer pasture management model (Savini et al. 1995).

\section{RESULTS}

\section{Model}

The conceptual model that we built with experts on the functioning of a summer pasture SES comprises a management submodel and a biophysical submodel, both based on a typology of summer pasture vegetation (Fig. 4).

\section{Management model}

The summer pasture management model comprises five interlinked spatial and time scales (Table 4) and makes it possible to define the functions expected from summer pasture vegetation at different management scales. The first three of these five scales (day, pastoral season, summer pasture season) coincide with the scales previously proposed by Savini et al. (1995) who identified and described the notions of "grazing sector," "grazing route," and "allotment." The experts considered these scales to be still highly relevant to describe management, but to be reviewed with an eye to managing the hazards inherent to each of these scales. Two longer management scales were added, which were necessary to describe actual adaptations and transformations: the first encompasses the entire year to consider the interactions between summer pastures and associated farms; the second considers the long-term (i.e., from a couple of years to several decades) with respect to the different spatial scales (changes in climate, vegetation, system managers, characteristics of the associated farms and their objectives for the summer pastures, etc.). We illustrate for a real case the spatial extension corresponding to different management scales: grazing sectors used at the daily and pastoral season scale, allotments corresponding to the pastoral season scale, the whole summer pasture corresponding to the summer pastures season scale, and the farms fields used for haymaking and grazing in spring and autumn corresponding to the annual scale (Fig. 5). 
Table 3. Elements conferring resilience to the different levels of summer pasture management. For each element, the generic criterion identified by Walker and Salt (2012) is indicated in brackets.

\begin{tabular}{llll}
\hline \hline $\begin{array}{l}\text { Spatial and temporal } \\
\text { management scale }\end{array}$ & Human & Herd \\
& Resource \\
\hline
\end{tabular}

Day and grazing route

Herders, with their know-how and knowledge of Behaviour of the livestock regarding the summer pasture [tightness of feedback], different techniques of shepherding [diversity] the capacity to use the vegetation [diversity, tightness of feedback]

Functional diversity of the vegetation in the allotment, diversity of sector configuration [diversity];

Configuration of the allotment: position of equipment and grazing sectors, ease of herd movement [diversity, modularity]

Allotment and pastoral season

Herders, (as above) [tightness of feedback]; Livestock farmers, depending on their involvement with the summer pasture (as above) [tightness of feedback] and on their collective motivation [social capital: leadership]; Herder-farmer relations [tightness of feedback, social capital: trust];

Availability of farmers (labor) [reserves, modularity]

Summer pasture and summer pasture season As above

Buffering capacity (genetic, health status, zootechnical objectives) [reserves];

Level of livestock needs (with respect to production cycle) [diversity]
Vegetation response diversity: supports availability of grass regardless of climatic hazards (Fig. 6, part 3, dark green, and causal maps in Appendix 1)

[diversity, modularity];

Preservation of supplementary resource in management [reserves]
Year and summer pasture-farm system

Relationships between farmers in the pastoral association, functioning rules [diversity, social capital, tightness of feedback];

Relationships with extension officers, sources of information [openness, tightness of feedback, social capital: social network];

Hiring of herders, requiring the support of professional networks [openness, social capital]
Selection criteria for dates, summer pasturing livestock numbers and needs [tightness of feedback]; Health status [reserves]; Genetic and behavioral differences between herds (breeds, selection criteria, previous learning) [diversity] Ability to buy and sell livestock to adjust to resources [openness]

\begin{abstract}
Diversity of soil and climate conditions on the summer pasture (aspect, elevation, slope, soil types) not to suffer from the same events everywhere [diversity, modularity]; Existence of a supplementary resource to be used at any time in the season [reserves]
\end{abstract}

Bridging resource between farms and summer pasture to be able to adapt carrying capacity [reserves] or off farms: purchased fodder, pasturing outside farm land [openness];

Resources that can be grazed at different times (standing fodder stock) on the farms [diversity];

Use of other summering areas in addition to the summer pastures [modularity, diversity]; Diversity of farming systems (location, functioning, weather experienced, and weather sensitivity) [diversity];

Number of farms [modularity]
Long term

Change in pastoral association members, farm selection criteria [diversity, modularity]; Learning [tightness of feedback]
Livestock selection criteria (hardiness) [reserves];

Diversity of genetic selection criteria between farms [diversity];

Changes in the size of the livestock population [reserves];

Herd learning ability [diversity]; Changes in the herds and in genetic selection criteria across farms [diversity]
Changes to spatial organization and equipment: change in available land, access to parcels [reserves], vegetation diversity at different scales [diversity]; Summer pasture practices (grazing, maintenance): change in the quality of vegetation types (see state and transition model in Appendix 1) [reserves] and in the diversity of vegetation [diversity]; Shift in the forage systems and choice of farms during their replacement [diversity, modularity]

\section{Vegetation typology}

Our novel management model fosters the adoption of a new point of view on vegetation, which is no longer considered in terms of the quantity of resources that it produces but instead in terms of the functions it can fulfill. Consequently, at a finer spatial scale than the summer pasture, different pastoral subfunctions were identified corresponding to the different types of vegetation. As in previous typologies, the functions fulfilled by different vegetation types depend on their productivity and palatability, but their management flexibility and their sensitivity to different climate hazards and pastoral practices were incorporated as new criteria.

A typology comprising nine main types of vegetation was built by the experts who participated in the modeling. These vegetation types were defined in a sufficiently generic way so as to be valid 
Table 4. The five spatial and time scales of summer pasture management.

\begin{tabular}{lll}
\hline \hline $\begin{array}{l}\text { Time } \\
\text { scale }\end{array}$ & Spatial scale & System managers \\
\hline
\end{tabular}

Day

Grazing route (route followed by the herd during the course of the day): made up of a series of sectors (physical units) whose characteristics determine a specific spatial and feeding behavior for the herd
Self-sufficient herder(s) on the summer pasture (this scale has no meaning for summer pastures without permanent shepherding)
Depending on daily events (weather, availability of the herder), composing the daily ration of the herd via a succession of different vegetation types while adapting to the herd's behavior (based on knowledge of the summer pasture and vegetation) and influencing its feeding behavior (more or less selection among the plants grazed) through different types of herding methods

Manage the succession of grazing routes to ensure that resources are sufficient in terms of quantity and quality during the entire season and the livestock farmer(s), who may occasionally get involved in collective tasks or regulate livestock numbers and needs (through sorting, bringing part of the livestock up or down)

Summer pasture season (duration: three to four months)

The entire summer pasture As above

Structure the use of different allotments according to phenology, capacity to remain as standing fodder stocks, and quantity of grass on the allotments

Year

Summer pasture-farm system: summer pasture Farmer(s)

(s) and the farm(s) that use them

Choice of number and types of summer pasturing livestock (dietary needs, tolerance to dietary deficiency), summer pasturing dates, and zootechnical management (presence or not of sires in the summer pasture, for example)

Long term

All of the previously mentioned spatial scales

Farmers and herders (the group of herders and farmers can change over the years)
Manage the trajectory of the vegetation through practices and through the configuration (equipment, parcels) of summer pastures and farms; decide main zootechnical objectives for farms (type of production, numbers, economic model, selection criteria, reproduction and selling periods, livestock learning, etc.), the associated technical management elements, and the functions attributed to summer pastures in this management system across the French Alps. Potential functions were defined for each type: main functions and functions for adaptation to adverse events at any management level (see Appendix 1 for details). Here, we focus on a single vegetation type, called "productive" by the experts, to illustrate how these types were characterized and how links between their characteristics and functions were made (Fig. 6). This type corresponds to different vegetation, with frequent dominance of Dactylis glomerata in the northern Alps and Agrostis capillaris in the southern Alps. This type of summer pasture vegetation, found on areas previously mowed on low summer pastures, produces 5 " 6 tonnes $\mathrm{ha}^{-1} \mathrm{yr}^{-1}$ of forage. The vegetation in these areas grows early but its use is not flexible (rapid drop in digestibility and palatability). On the summer pastures where it is present, its main function is to provide a large portion of the fodder at the start of the summer pasture season, generally during the first pastoral season (Fig. 6, part 3). Regrowth is also critical for this type of vegetation because it provides fodder at the end of the summer pasture season.

In addition to their main functions, the different vegetation types can fulfill hazard adjustment functions at different management levels, depending on their sensitivity to different hazards and practices (see Biophysical model). For example, at the yearly scale and for the summer pasture-farms system, the productive vegetation type is useful as a buffer between the farms and the summer pasture because it can accommodate early grazing, if necessary, when fodder runs out early in the valley, and can also support a second grazing period at the end of the season, especially given its location at lower altitudes where the first bouts of bad autumn weather are not so severe (Fig. 6, part 3).

Finally, the vegetation's potential functions must be nuanced according to each real summer pasture situation, depending on the sector and allotment configurations and on the usage constraints that make it possible or not to use the vegetation in an optimal manner, as described in the model. Hence, the productive vegetation type, which does not lend itself well to late initial grazing, may nevertheless be grazed at an advanced stage (generally toward the end of July) in configurations in which there is no other vegetation able to ensure forage for the herds during this period. 
Fig. 5. Functional breakdown of a summer pasture in the Ecrins National Park into allotments and sectors (according to Savini et al. 1995). The management at the year time scale is illustrated with the parcels of the two livestock farms using the summer pastures.

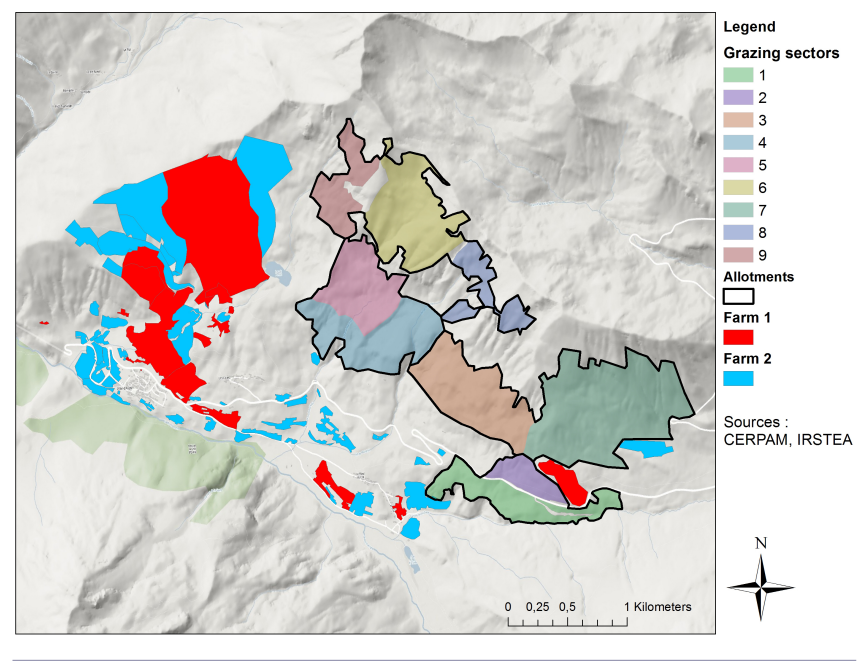

\section{Biophysical model}

The biophysical model is detailed extensively in Appendix 1; in the following, we present the main lessons from its construction, thus aiming to highlight key features of the approach. The biophysical model comprises two parts. The first part, made up of causal maps at the scale of a summer pasture season, explains the effects of climatic hazards and pastoral practices on forage dynamics during the summer pasture season. At this scale, it demonstrates the importance of vegetation characteristics that vary interannually (productivity, phenology) and during the season (nutritional quality and relative palatability of different species). These aspects have not previously been included in technical summer pasture management tools. The causal maps may be used to explain the characteristics of each vegetation type (Fig. 6, vegetation type name and description) and their level of sensitivity to climatic hazards and pastoral practices (Fig. 6, parts 1 and 2), making it ultimately possible to explain the functions they fulfill (Fig. 6, part 3).

The second part of the biophysical model comprises a state and transition model based on the vegetation typology. It describes the effects of practices and climate on the shift from one type of vegetation to another and on the qualitative changes in each type of vegetation (see Appendix 1). It aims to support an analysis of the management model in the long term.

The pastoral practices implemented and climatic parameters can shift individual vegetation types along alternative qualitative pathways. For example, qualitative variations in the productive vegetation type (Fig. 7, green boxes) mainly regard a gradient of floristic diversity that is associated with varying digestibility and flexibility of use and depends on grazing period and grazing pressure (Fig. 7, grey boxes). This vegetation type can also shift to other types (e.g., "scrub," then "forest") in the case of repeated incomplete vegetation consumption (Fig. 7, blue and red boxes).

\section{Template}

Based on the characteristics of this model and on the generic criteria conferring resilience to SESs (Table 2; Walker and Salt 2012), we identified for each cell of the template the elements likely to confer resilience to summer pastures and reported them in the template (Table 3, organized according to the human-herdresource triad and to the five scales of the management model). In the following, we analyze which generic criteria seem the most meaningful in our model and we explain and illustrate the links between some elements indicated in the template and the conceptual model. Some criteria appear frequently, whereas others appear to correspond more rarely to a concrete reality.

First, the availability of "reserves" seems essential to face a disturbance, be it a surplus of usable resources (on farms, on the summer pasture, or in the form of bridging resources between farms and summer pasture; Fig. 6, dark green and blue lines), well-fattened livestock that can cope with a difficult period, or labor available to overcome an unplanned problem. Second, "diversity" is a critical characteristic that can be used at all levels to make adjustments in response to a variety of adverse events at different management levels (diversity of vegetation, of exposure to climatic conditions of livestock needs, of opinions on management, etc.; Fig. 6, light green and dark green lines), as is "tightness of feedback," be it the capacity of managers to detect a disturbance and respond, ecological feedbacks, or the capacity of livestock to change resources. Third, there is very little "modularity" between the system's elements. The management of a summer pasture is essentially seen as a coherent whole with strong interdependencies, and it is only at the summer pasturefarm system scale that the strong autonomy of the different farms can confer modularity to the system: if one farm disappears or switches to another summer pasture, the others are not expected to be affected. Fourth, "openness" makes sense at two levels (Table 3): regarding the interaction between the summer pasture and the farms (livestock flows) and for the summer pasture-farm system as a whole (livestock input and output and feed purchase and sale). Resilience of the system is then conferred by the capacity to control these flows, i.e., to move livestock between the summer pasture and the farm, and to ensure fodder autonomy to farms (or control the cash enabling the purchase of feed). Finally, "social capital" is fundamental for management of summer pastures because many different actors interact within (farmers, herders) and outside these systems.

\section{Operationality of the conceptual model applied to trial case studies}

In this section, the operationality of the model is demonstrated with two successive comparisons of pairs of summer pastures. We focus successively on: (1) the use and management of vegetation diversity, and (2) system management by the group or community of farmers and herders.

\section{Use and management of vegetation diversity}

We first present the way in which vegetation diversity is used by livestock farmers and shepherds to cope with climatic hazards on the two summer pastures called Dar and Cro, each used by a single sheep farm (Table 5). The different management scales represented as the rows of the template (Table 3 ) prove to be relevant and operational to analyze this aspect. This five-row structure was transferred to Table 5. In these two examples, 
Fig. 6. Description of the "productive" vegetation type. Elements are formalized in terms of agronomic properties, sensitivity to hazards, main functions, adjustment functions, and sensitivity to practices.

Productive type : Productive vegetation, early, of good quality but little aptitude to late grazing (rapid drop in quality). Found on deep and fertile soils.

\begin{tabular}{|c|c|c|c|c|}
\hline Approximative periods & June & July & August & September \\
\hline
\end{tabular}

\section{Legend - sensitivity}

very sensitivie: important negative effec

moderately sensitive: low negative effect positive effect

\section{Sensitivity to climatic hazards}

\begin{tabular}{|l|l|l|l|}
\hline Frost: lost in quantity and quality & & \\
Heat: maturity acceleration and rapide lost of quality & & \\
\hline
\end{tabular}

\section{Sensitivity to practices}

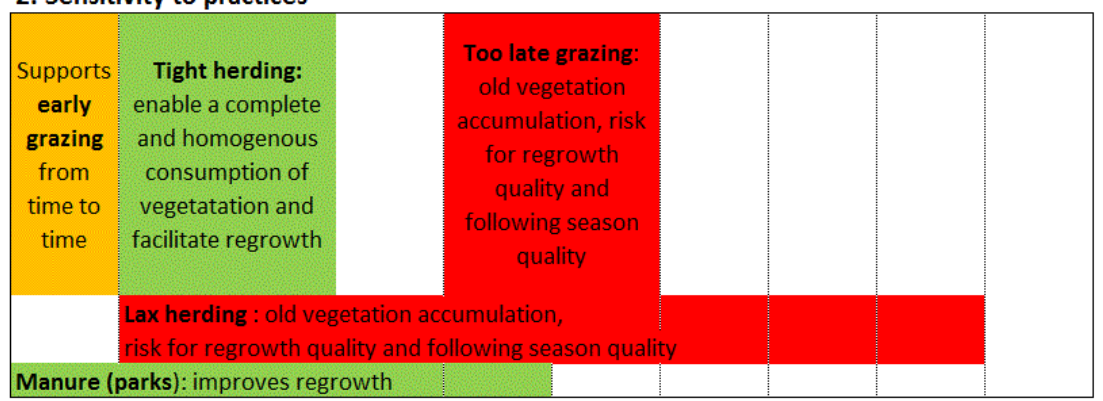

3. Functions

\begin{tabular}{|l|l|l|l|l|}
\hline $\begin{array}{l}\text { Main function, general case } \\
\text { Main function, particular case }\end{array}$ & $\begin{array}{l}\text { Grazing around } \\
\text { the heading stage }\end{array}$ \\
\hline Adjustment function at a daily scale & & $\begin{array}{l}\text { grazing at } \\
\text { beginning of senescence fibers in the ration complementary with } \\
\text { less fibrous vegetation }\end{array}$ \\
\hline $\begin{array}{l}\text { Adjustment function at the season scale } \\
\text { Adjustment function at interaction between } \\
\text { summer pasture and farms }\end{array}$ & $\begin{array}{l}\text { Early grazing } \\
\text { (limits the regrowth) }\end{array}$ \\
\hline
\end{tabular}

Fig. 7. Extract from the state and transition model. Qualitative variations of the "productive" vegetation type and possible shifts to other types.

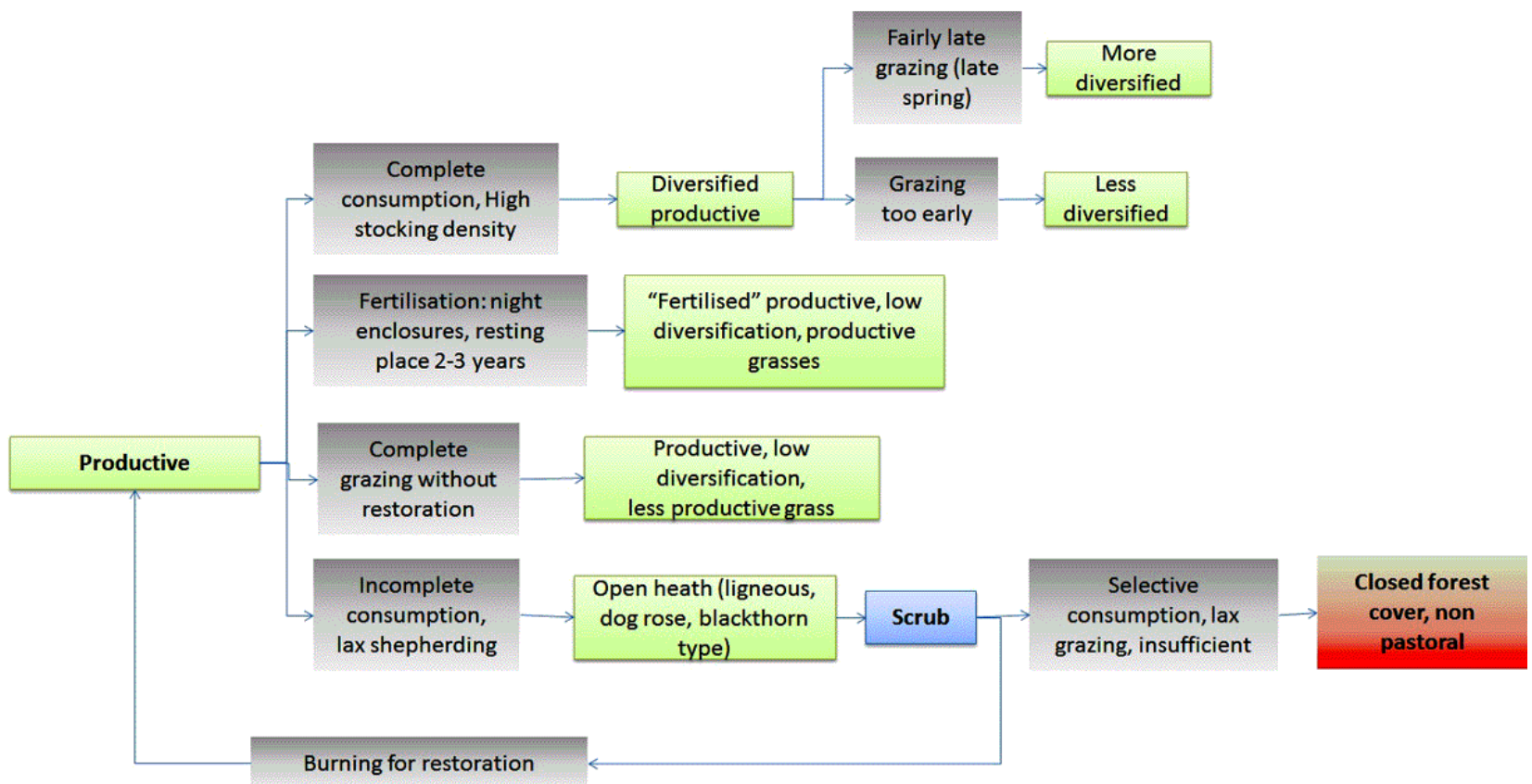


Table 5. Comparison of the way in which vegetation diversity is used at different management levels on two individual summer pastures used for sheep grazing belonging to the Sentinel summer pastures program (Dar and Cro cases).

\begin{tabular}{lcc}
\hline \hline & & Summer pasture \\
\cline { 2 - 4 } $\begin{array}{l}\text { Management } \\
\text { level }\end{array}$ & Dar & \\
\hline
\end{tabular}

Configuration and types of dominant vegetation Dry plateau (1300 m a.s.l.): intermediate subalpine grasslands (high intratype diversity), grazing woodland; Ridge (1900 m a.s.l.): intermediate subalpine grasslands of mediocre quality; no water

Day and grazing route

Use of functional diversity of vegetation to balance the daily rations (between rich and fibrous vegetation) and to adjust for weather conditions (between open spaces for sunny days and forest for rain and heatwaves)

Pastoral season

Use of the diversity of vegetation responses to drought, the main hazard affecting grazing on this summer pasture with shallow soil (increased use of undergrowth that is less drought sensitive)

Season and summer pasture

Because of the shortage of water in the ridge area, capacity to use the altitudinal gradient is limited. Functional vegetation diversity is used to compensate: shepherds will use the differing capacities across vegetation types as standing fodder stocks remain palatable through the season to ensure sufficiently nutritious resources throughout the summer pasture season

Year and summer pasture-farm interaction

Wide variety of vegetation on the farm used in a different way each year to adjust to hazards. High capacity to shift summer pasture ascent and descent dates (to compensate for the absence of early growth and for variations in productivity)

Long term

Drop in quantity and diversity of resources available on the summer pasture: predators (wolf) that reduce the possibility of grazing in the undergrowth. Gradual reduction in time spent on the summer pasture because of the use of new areas at an intermediate elevation between the farm and the summer pasture but with a low level of land tenure control. Improvement to the equipment (water reserves) for better use of the existing resources on the summer pasture. Management of grazing pressure to preserve the functional diversity of the vegetation
North side slope (1500-2500 m a.s.l.): grazed woodland, productive vegetation, intermediate alpine grasslands

Use of functional diversity of vegetation to balance the daily rations (between rich and fibrous vegetation) and to adjust for weather conditions (between open spaces for sunny days and forest for rain and heatwaves)

Use of phenological diversity between vegetation types to adapt to annual climate conditions

Use of the diversity of conditions allowed by altitudinal variation providing sufficiently rich resources throughout the summer pasture season
Many constraints on the farm (small parcels, no fencing, access constraints) limiting the adjustment options for benefitting from vegetation diversity and limiting the capacity to adjust summer pasture ascent and descent dates; hence, adjustments need to be made on the summer pasture

Grazing pressure adapted to the exact renewal of the resources on the open spaces and insufficient in encroached pastures, where forestry activities are required to control shrub colonization vegetation diversity is an essential element that livestock farmers and shepherds know how to take advantage of to deal with weather-related disturbances, in very different ways depending on the configuration of the summer pastures and farms and on their external constraints.

At the daily management scale, we identified functional diversity as a key factor for adaptation (Table 3 ) because it enables the SES to cope with daily weather variation. Indeed, on the summer pasture Dar, as on Cro (Table 5), at this scale, the shepherds make adjustments using functional diversity through the combination of rich vs. fibrous grass and between open spaces vs. understory pastures. At the pastoral season scale (Table 3), response diversity provided by different sensitivities across vegetation types to climatic hazards is essential. On the two pastures, complementarity between open and understory pastures is mobilized, but this time for their different responses to drought on Dar and for the phenological spreading resulting from shading by trees on Cro. At the scale of the summer pasture season (Table 3 ), we identified the diversity in altitudinal elevation as a major factor, which is fully mobilized on Cro. On Dar, on the contrary, this aspect is hardly mobilized for adaptation because of the shortage of water on the ridge area. Instead, shepherds use functional diversity in a different and original manner (Table 5). At the annual scale (Table 3), the farmer that uses Dar uses a great diversity of vegetation types (different types of meadows and rangelands, orchards) that he mobilizes to adjust the time spent on Dar each year. The farmer using Cro also uses a great diversity of vegetation types, but because of different constraints (small parcels, no fencing, access constraints), is unable to mobilize it to adjust dates and time spent on summer pasture. Over the long term, grazing practices appear stable on Cro, whereas on Dar, the 
farmer has increasingly resorted to diversification of grazing resources at the annual scale to make up for decreasing capacity to mobilize functional diversity on the summer pasture because of the arrival of wolves that restrained access to understory pastures.

The template (Table 3) allowed us to analyze and understand the way the diversity of resources is mobilized for resilience in these two contrasting cases. We used a qualitative figure to synthesize and illustrate the main differences in the way farmers and shepherds combine different types of vegetation diversity to maintain resilience for Dar and Cro (Fig. 8). The figure was constructed using an expert-based distribution of 12 points to four attributes of vegetation.

For Dar (Table 5, Fig. 8), because of constraints such as lack of water and predation, the use of vegetation diversity at different management scales is vital for system resilience. Although the system currently seems sufficiently resilient, uncertain property rights on-farm threaten the maintenance of vegetation diversity at the annual scale, which is the main adjustment mechanism following the loss of diversity on the summer pasture (because of predation problems that restrain access to undergrowth). Thus, it would be wise to find ways to secure diversity at other management levels. Extension officers familiar with this summer pasture suggest providing water reserves on the ridge; the use of several summer pastures and collective transhumance are among some of the avenues to be explored, options which would have to be discussed with farmers. For Cro (Table 5, Fig. 8), resilience is permitted by altitudinal variation and a surplus of very flexible vegetation in the undergrowth. Forestry management maintains balance in the habitat. The analysis of Cro highlights that the main risk stems not from climate change but from the arrival of wolves on the summer pasture, which prohibits access to the undergrowth under current shepherding practices and reduces adjustment options, particularly at the day and pastoral season levels. Our model, focusing on specific resilience to climatic perturbations, does not directly analyze resilience to this type of perturbation. Nevertheless, it detects that a better use of vegetation diversity on the farm would not be sufficient in this scenario; it would probably be necessary to accept a disruption and a transformation of the system (converting to a cattle summer pasture and giving up the steepest slopes, for example).

To conclude, although these SESs appear to be relatively secure at first impression, the analysis highlights that the situation remains precarious on these two pastures. Such challenges can stimulate novel thinking about solutions to regain resilience by exploring new adjustment options.

\section{Collective summer pasture and summer pasture-farm system management}

Until recently, the framework for summer pasture management analysis (Savini et al. 1995, 2010) considered that there was a single herder-manager. However, there are often several herders on a summer pasture, and livestock farmers also participate in management and thus must be considered as integral parts of the system (Eychenne 2008). Depending on the farmers' involvement on the summer pasture, their knowledge of the functioning of the summer pasture, the daily situation, and the farmers' and herders' communal functioning rules, the system's capacity to cope with disturbances can vary widely, as illustrated in the comparison between two collective summer pastures called Sur and Pon, used by several sheep farms (Table 6 ). In both cases, the capacity to act in an isolated manner on each farm and on the summer pasture is very limited (Eychenne and Lazaro 2014). Thus, to improve resilience, it will be necessary to think at the summer pasturefarm system scale. For Sur, this will require some training and the creation of collective dynamics, whereas for Pon, farmers are used to thinking and operating at this management scale.

Fig. 8. Star diagram showing the preferential scales at which farmers and shepherds mobilize vegetation diversity to maintain resilience of their system (Dar and Cro cases). Scores for each scale of vegetation diversity were obtained by allocating for each summer grassland a total of 12 points across the four scales, based on expert analysis of the functioning of each summer grassland.

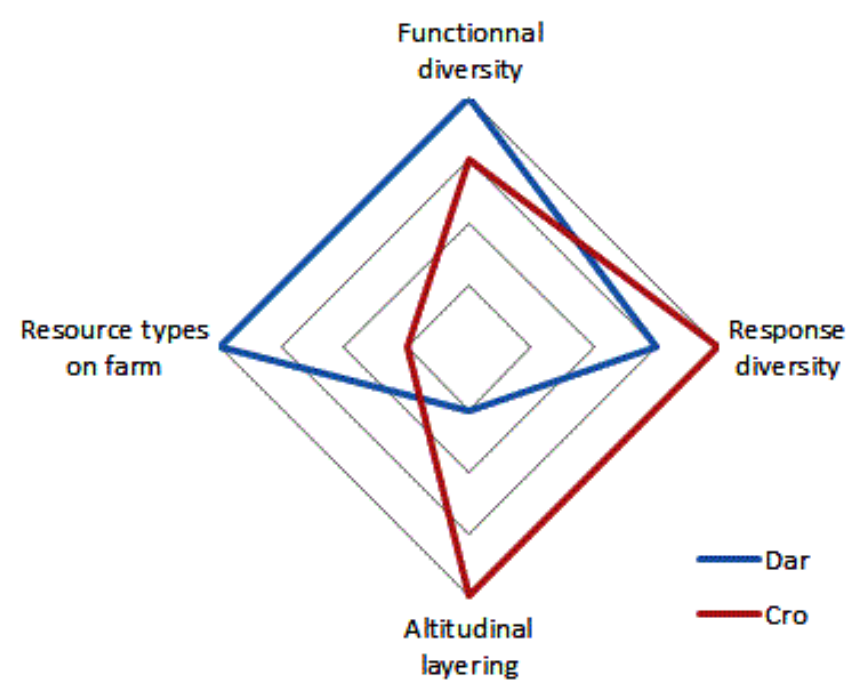

\section{DISCUSSION}

\section{The main interest lies in the modeling process}

We only tested our model for four case studies, and its generic capacity, i.e., its applicability to all summer pastures in the Alps, still needs to be demonstrated. Nevertheless, through the analysis of these four case studies, we have shown that this model, associated with the resilience analysis template (Table 3 ), could be an interesting heuristic tool with which to analyze the management of real cases. We believe that from a scientific point of view, the main interest stems from the conceptual modeling process that allows the experts to formalize and share knowledge and hence to enable all of the different actors involved in the approach to benefit from new learning (Tengö and Belfrage 2004, van Kerkhoff and Lebel 2006, Darnhofer et al. 2010b, Farrié et al. 2015). Thus, this modeling process is a learning process that appears helpful to adopt and promote adaptive management, therefore operationalizing resilience. In many situations, adaptive management is a necessity. Adaptive management enables either adaptation or transformation of systems (Hagmann and Chuma 2002, Lynam et al. 2002, Darnhofer et al. 2010a). Learning processes are an important key for adaptive management (Roling and Wagemakers 2000). Here, the process led experts to 
Table 6. Comparison of the management of two collective summer pastures for grazing sheep (Sur and Pon cases).

\begin{tabular}{l|ccc}
\hline \hline & & Summer pasture & \\
\cline { 2 - 4 } $\begin{array}{l}\text { Management } \\
\text { level }\end{array}$ & Sur & Pon & \\
\hline
\end{tabular}

Work collective

Local farmers (five different farms) and one hired shepherd Transhumant farmers who take turns shepherding (three different farms)

Knowledge and management rules

Farmers: no clear vision of the resources on the summer

Good knowledge of resources on the summer pasture and significant pasture; no rules for adjustment to dates or sheep numbers on capacities to adjust management both on farms and summer pasture the summer pasture; limited capacities of detection and response by adjusting farms and summer pasture stocking rates

Adaptations

Temporary adjustments mainly by the shepherd on the summer pasture
Gradual adjustments at different levels in response to a lack of reserves and diversity of pastoral resources: delay in the ascent date, grazing of new areas before and after summer pasturing, adjustments between farms year-round

Conclusion: resilience of the summer pasture

Climatic hazards hard to manage for shepherd; local

Management more favorable to the preservation of resilience in the long overgrazing; risks of long-term resource degradation and loss term of resilience

reconsidering summer pastures as dynamic systems in a dynamic environment (Coquil et al. 2010). This will undoubtedly influence the advice given by our experts to farmers and herders. For future development actions, we could also imagine involving farmers and herders more directly in the modeling process (Gouttenoire et al. 2010).

In spite of its novel dynamic nature, one of the model's current limits is related to uncertainties in the long-term effects of climate on vegetation dynamics. Whereas the experts were very precise regarding the effects of pastoral practices on vegetation, going so far as to describe qualitative gradients for each type of vegetation, only a few hypotheses were put forward concerning climate effects because of a lack of empirical observations and established scientific knowledge. This aspect of the model can undoubtedly be improved later, with a similar modeling process, after further research and once actors start witnessing wholesale vegetation change.

We emphasized previously that the modeled system was restricted to a pastoral point of view and to climatic perturbations. Applying the same modeling process would make it possible to broaden the boundaries of the system considered. It would be interesting, for example, to build a new model of summer pastures incorporating biodiversity issues, which could facilitate the inclusion of agrienvironmental issues (Schermer et al. 2016, Darnhofer et al. 2017). Further developments should also consider other types of perturbations such as predation, which we identified in our case studies as a major perturbation that strongly interacts with adaptation to climatic perturbation. Lastly, the absence of the regional management scale in the model (Baur and Binder 2013) can be questioned. Other actors influencing the management of summer pasture (extension officers, government bodies, elected officials, environmental associations, etc.), and institutions in general (Schermer et al. 2016), were not included. This scale could be integrated in further models, which would doubtless widen the scope of opinions on summer pasture to understand better their multifunctional nature instead of only focusing on their pastoral interest.

\section{Going further in the modeling toward quantitative implementation}

The conceptual model remains highly qualitative, including the biophysical component (Appendix 1). Causal relationships are established between climate or livestock grazing and vegetation without quantifying these interactions. The different vegetation types are simply characterized comparatively (and not in absolute terms) with respect to their level of sensitivity to different weather parameters and practices. In the state and transition model for describing long-term dynamics, experts were only able to distinguish time frames of roughly a decade from longer time frames. This qualitative character is innate to expert-based modeling and can be a limit, for example, to introducing digital simulation. However, from a management support point of view, this is not an obstacle to understanding the mechanisms and to considering adaptation options.

Nevertheless, going further in the modeling process through an informatics tool could be an interesting further step. Agent-based modeling, which is frequently used for participatory modeling, should facilitate the (semi)quantitative implementation of the model (Voinov and Bousquet 2010, Etienne 2014, Murray-Rust et al. 2014). First, it would require identifying the most important drivers and simplifying the model, thus improving its generic applicability and transferability for stakeholders (Bommel 2009). Second, it would provide a tool to identify the outcomes of different trade-offs. Finally, it would enable testing and quantifying the effects of alternative climate scenarios that have been downscaled for the Alps (Verfaillie et al. 2016).

\section{Contribution to livestock farming systems research}

Previous research on resilience has already been used to characterize adaptation strategies for livestock farming systems faced with disturbances (Dedieu and Ingrand 2010, Nettier et al. 
2010, Astigarraga and Ingrand 2011), but these approaches have not gone so far as to detail adaptation mechanisms at the interface between the social and ecological dimensions. Our results are in line with recent research. They complement studies estimating a theoretical potential allowed by diversity at the parcel or forage system scales (Martin et al. 2009, Jacquot 2012) by extending them for summer pastures and by showing how diversity can be leveraged by shepherds in practical terms. Other criteria conferring resilience identified in our template (Table 3) were already known and taken into account in the field, for example: (1) the importance of the knowledge of livestock farmers and herders (Oteros-Rozas et al. 2013), even if it had not always been considered in terms of resilience (Meuret and Provenza 2014), or (2) criteria linked to herd management as a way of dealing with disturbances was also studied previously (Blanc et al. 2010, Jacquot et al. 2010, De La Torre et al. 2015) but was rarely taken into account in management (Ollion 2015) and technical recommendations.

Climate change represents a high source of uncertainty: the magnitude and patterns of climate change per se are uncertain and so are its long-term effects on the system, as shown by the difficulty for experts to assess them. Our work confirms, following Darnhofer (2014), that resilience thinking proves to be fruitful to manage farming systems in a context of great uncertainty.

The most interesting development brought by this work to farming systems research is linked to the concept of panarchy proposed by Gunderson and Holling (2002). Our model is in line with this understanding of the functioning of SESs. Different management scales are conceived as corresponding semiautonomous systems: sectors, allotments, summer pastures, summer pasturefarm systems.

Our work on summer pastures and the study cases we presented illustrate how different semiautonomous systems interact at different scales. We have seen that the way the diversity of vegetation is used responds to different logics according to the scale and subsystem considered: from mainly a diversity of response to hazards at the pastoral season scale (corresponding to an allotment subsystem) to functional diversity and altitudinal elevation diversity at the summer pasture season scale (summer pasture system). However, the same vegetation is also used at different time scales in these different systems. Within each system, the management has its own coherence to ensure feeding the herd and the persistence of the resource. All the art and science of shepherding (Meuret and Provenza 2014) is to achieve the articulation of different levels of coherence: within-allotment coherence and within-summer pasture coherence, but also summer pasture-farm systems coherence (considering farmers' objectives).

Faced with climate change and from a panarchy point of view, the challenge is to preserve the pastoral function of summer pastures (their ability to feed herds during summer), and therefore to develop their adaptability and avoid reaching thresholds that would lead to their transformation (for example, pastoral use being abandoned). As the different organizational levels interact, it is possible to transform at higher or lower levels to preserve the functions of the summer pasture as a system. For example, at a lower scale, an allotment very sensitive to drought with no adjustment possibility could be abandoned and reorganizations could be made on the other allotments (new equipment, new sectors explored). This important transformation of one subsystem, the allotment, supports the improvement of the adaptability of the whole summer pasture. At an upper scale, we already mentioned, in the case of Cro, a potential farm transformation to improve the summer pasture adaptability to predation. In the sentinel summer pasture program, we also already observed changes in the lambing schedule on farms that prevented the ascent of lambs to summer pastures. This important transformation for farms (production of suckling lambs vs. grazing lambs) reduces both animal needs and animal numbers on summer pasture, thereby improving the adaptability of summer pasture.

Cross-scale linkages have been conceptualized in agronomic sciences but remain difficult to implement. Our framework, applied here to the case of summer pastures, appears promising for analyzing adaptation and transformation of any farming system by articulating different scales (Mottet et al. 2006, Dedieu et al. 2008, 2010): field, farm, landscape, regional, national, or global scale.

\section{Contribution to the operationalization of resilience theories}

Here, we demonstrated that the framework proposed by Walker and Salt (2012) could support the analysis of the resilience of a summer pasture SES to climate hazards for operational use. We believe that two aspects of our implementation of Walker and Salt's (2012) framework explain the capacity of our model and template to capture the functioning of a summer pasture and to identify what makes it resilient. We used a multidimensional conceptualization of the resilience of a system. This allowed us to adopt a comprehensive approach of ways to be resilient and to describe different mechanisms of resilience on summer pastures, which is more operational than a quantitative evaluation of resilience. We next discuss three major methodological elements that need to be considered in such a process.

Balancing the two dimensions of a social-ecological system First, assigning equal significance to both the social and ecological dimensions of the SES in the modeling is critical. Although theory recommends adopting a balanced position, in practice, often only one of these dimensions is analyzed in great depth, probably mainly because of disciplinary isolation. Thus, Rissman and Gillon (2017) show that the ecological dimension is neglected in many SES studies. Among the research dealing with social-ecological resilience of agricultural or pastoral systems, quite often the emphasis on the two dimensions is uneven. Sometimes, the focus is on the system's ecological dimension, and the social mechanisms are analyzed in a superficial manner (Soane et al. 2012); this generally occurs when the challenges are primarily environmental and also when the research is led by ecologists. At other times, the focus is on the system's social dimension, and the ecological dimension is only studied superficially. This is often the case for the analysis of agricultural systems resilience (Milestad and Darnhofer 2003, Darnhofer 2010, Darnhofer et al. 2010b, Carlisle 2014, Tittonell 2014), but also in recent studies focusing on biodiversity (Oteros-Rozas et al. 2013).

For pastoral systems in particular, in which the social and ecological dimensions are closely linked, a balanced approach is essential (Reid et al. 2014). Our model thus makes it possible to understand the coherence between the practices of livestock 
farmers and herders and the functioning of pastoral environments. However, even if we strived to build a balanced model of social and ecological dimensions, the modeling process, while limiting the model to a strictly pastoral point of view, led us to limit also the social dimension to an agronomic point of view. We did not consider explicitly economic or sociological aspects in the model. The analysis of case studies highlights that other considerations (sociological in particular, see Table 6) are also important in understanding reasons behind choices made by farmers and shepherds and should be integrated explicitly in models for a better understanding of management and its adaptation potential.

Defining the boundaries of a social-ecological system in relation to its social dimension

Second, we defined the boundaries of the SES through its social dimension: we initially considered the summer pasture as a management unit with its management subunits and then characterized its ecological functioning. Quite often, the opposite approach is taken in resilience research (Miller et al. 2010). For instance, in the case of summer pastures, Soane et al. (2012) defined different interacting systems according to their ecological characteristics. This may seem coherent when examining environmental issues but could be a limit to reaching an understanding of management coherence and coming up with tangible management recommendations.

Defining a scale of analysis coherent with the type of actions to be implemented

Finally, we examined a relatively small-scale management system in comparison to examples presented by Walker and Salt (2006, 2012) that focus on larger regional scales. We believe that in the European and many other mountain contexts, this scale is relevant for focusing on the actions of stakeholders that manage the system day to day (here, the herders and farmers). Consequently, the system was modeled with these stakeholders considered as the pilots of the whole system. They are not considered as elements of the system that researchers can try to act on to modify the system. Rather, they remain the ones who will act on the system, thus fully recognizing their agency. Therefore, we adopted a stance in which they are partners with whom one can directly deliberate and construct management practices, instead of being stakeholders whose behavior one attempts to influence, for example, through public policies.

The main focus has been at the summer pasture scale (studied in interaction with lower and upper scales). From another point of view, the main focus could have been at a lower scale (to focus on issues of vegetation dynamics, for instance) or larger scale (regional, for example, if macroeconomic issues were considered of primary importance). These choices would have led to very different models.

From an operational perspective, the choices of scale and the stakeholders included and excluded from the system are a critical consideration because they will determine the types of development actions that will be implemented and whether the accompanying change will be predominantly top-down or bottom-up.

\section{CONCLUSION}

We implemented Walker and Salt's (2012) framework, which proved to be promising for analyzing the resilience of pastoral systems with a view to improving their management. The framework presents a multidimensional vision of the resilience of a system and offers a way to analyze the different ways of being resilient while articulating different management scales.

Our analysis template (Table 3), combined with the model of summer pastures, is an interesting operational tool, but we believe that the modeling process itself is of greatest interest. The modeling process is a learning process that made it possible to share and formalize knowledge. It allowed participants to "think resilience," i.e., to adopt a vision of summer pastures as dynamic systems in a dynamic environment. Thus, it is expected to allow experts to adopt or promote adaptive management methods. The use of a conceptual modeling process and the analysis of summer pastures through the prism of resilience are two promising elements for the development of new extension actions.

Responses to this article can be read online at: http://www.ecologyandsociety.org/issues/responses. $\mathrm{php} / 9625$

\section{Acknowledgments:}

We thank all of the experts who participated in the different participatory modeling phases: Simon Vieux, Ariane Silhol, Laurent Garde (Cerpam); Julien Vilmant, Bruno Caraguel (FAI), Thomas Romagny (ADEM), Muriel Dellavedova, Clotilde Sagot, Cédric Dentant, Richard Bonet (Ecrins National Park); Vincent Augé, (Vanoise National Park), Philippe Choler, Monica Cecilia Corona Lozada, Marine Gabillet (LECA), and Olivier Senn. The Sentinel summer pasture program has been supported by the French Ministry of Ecology (Directorate for Water and Biodiversity), the General Commission for Territorial Equity (FNADT-CIMA), the European Union (FEDER-POIA massif alpin), and the AuvergneRhône-Alpes and Provence-Alpes-Côte d'Azur Regions. The authors also received support from the ANR BiodivERsA REGARDS project ( ANR-12-EBID-004-01). This research was conducted in the Central French Alps LTSER, Zone Atelier Alpes.

\section{LITERATURE CITED}

Adger, W. N., T. P. Hughes, C. Folke, S. R. Carpenter, and J. Rockström. 2005. Social-ecological resilience to coastal disasters. Science 309(5737):1036-1039. http://dx.doi.org/10.1126/science.1112122

Allen, C. R., L. Gunderson, and A. R. Johnson. 2005. The use of discontinuities and functional groups to assess relative resilience in complex systems. Ecosystems 8:958-966. http://dx.doi. org/10.1007/s10021-005-0147-X

Anderies, J. M., C. Folke, B. Walker, and E. Ostrom. 2013. Aligning key concepts for global change policy: robustness, resilience, and sustainability. Ecology and Society 18(2):8. http:// dx.doi.org/10.5751/ES-05178-180208 
Anderies, J. M., B. H. Walker, and A. P. Kinzig. 2006. Fifteen weddings and a funeral: case studies and resilience-based management. Ecology and Society 11(1):21. http://dx.doi. org/10.5751/ES-01690-110121

Astigarraga, L., and S. Ingrand. 2011. Production flexibility in extensive beef farming systems. Ecology and Society 16(1):7. http://dx.doi.org/10.5751/ES-03811-160107

Baur, I., and C. R. Binder. 2013. Adapting to socioeconomic developments by changing rules in the governance of common property pastures in the Swiss Alps. Ecology and Society 18(4):60. http://dx.doi.org/10.5751/ES-05689-180460

Bennett, E. M., G. S. Cumming, and G. D. Peterson. 2005. A systems model approach to determining resilience surrogates for case studies. Ecosystems 8(8):945-957. http://dx.doi.org/10.1007/ $\underline{\text { s10021-005-0141-3 }}$

Benot, M.-L., P. Saccone, E. Pautrat, R. Vicente, M.-P. Colace, K. Grigulis, J.-C. Clément, and S. Lavorel. 2014. Stronger shortterm effects of mowing than extreme summer weather on a subalpine grassland. Ecosystems 17(3):458-472. http://dx.doi. org/10.1007/s10021-013-9734-4

Bernard-Brunet, J., and A. Bornard. 2004. La cartographie des végétations pâturées d'altitude par télédétection: un outil pour décrire leur diversité spatiale. Fourrages 179:319-334.

Blanc, F., B. Dumont, G. Brunschwig, F. Bocquier, and J. Agabriel. 2010. Robustesse, flexibilité, plasticité: des processus adaptatifs révélés dans les systèmes d'élevage extensifs de ruminants. INRA Productions Animales 23(1):65-80.

Bommel, P. 2009. Définition d'un cadre méthodologique pour la conception de modèles multi-agents adaptée à la gestion des ressources renouvelables. Dissertation. Université Montpellier II, Montpellier, France. [online] URL: https://tel.archives-ouvertes. fr/tel-00396803v3/document

Bornard, A., M. Bassignana, C. Bernard-Brunet, S. Labonne, and P. Cozic. 2007. Les végétations d'alpage de la Vanoise. Description agro-écologique et gestion pastorale. Quae, Versailles, France.

Brand, F. 2005. Ecological resilience and its relevance within a theory of sustainable development. UFZ Reports 03/2005. Helmholtz Centre for Environmental Research, Leipzig, Germany. [online] URL: https://econpapers.repec.org/RePEc: zbw:ufzrep:032005

Brown, V. A. 2010. Collective inquiry and its wicked problems. Pages 61-83 in V. A. Brown, J. A. Harris, and J. Y. Russel, editors. Tackling wicked problems through the transdisciplinary imagination. Earthscan, London, UK.

Cabell, J. F., and M. Oelofse. 2012. An indicator framework for assessing agroecosystem resilience. Ecology and Society 17(1):18. http://dx.doi.org/10.5751/ES-04666-170118

Calanca, P. 2007. Climate change and drought occurrence in the Alpine region: How severe are becoming the extremes? Global and Planetary Change 57(1-2):151-160. https://doi.org/10.1016/j. gloplacha.2006.11.001

Camp, E. V., W. E. Pine III, K. Havens, A. S. Kane, C. J. Walters, T. Irani, A. B. Lindsey, and J. G. Morris Jr. 2015. Collapse of a historic oyster fishery: diagnosing causes and identifying paths toward increased resilience. Ecology and Society 20(3):45. http:// dx.doi.org/10.5751/ES-07821-200345

Carlisle, L. 2014. Diversity, flexibility, and the resilience effect: lessons from a social-ecological case study of diversified farming in the northern Great Plains, USA. Ecology and Society 19(3):45. http://dx.doi.org/10.5751/ES-06736-190345

Carpenter, S., B. Walker, J. M. Anderies, and N. Abel. 2001. From metaphor to measurement: resilience of what to what? Ecosystems 4(8):765-781. https://doi.org/10.1007/s10021-001-0045-9

Carpenter, S. R., F. Westley, and M. G. Turner. 2005. Surrogates for resilience of social-ecological systems. Ecosystems 8 (8):941-944. http://dx.doi.org/10.1007/s10021-005-0170-y

CERPAM and Parc national des Ecrins. 2006. Diagnostic pastoral en alpages. CERPAM and Parc national des Ecrins, Manosque, France.

Choler, P. 2015. Growth response of temperate mountain grasslands to inter-annual variations in snow cover duration. Biogeosciences 12:3885-3897. http://dx.doi.org/10.5194/bg-12-3885-2015

Cifdaloz, O., A. Regmi, J. M. Anderies, and A. A. Rodriguez. 2010. Robustness, vulnerability, and adaptive capacity in smallscale social-ecological systems: the Pumpa Irrigation System in Nepal. Ecology and Society 15(3):39. http://dx.doi.org/10.5751/ ES-03462-150339

Collins, S. L., S. R. Carpenter, S. M. Swinton, D. E. Orenstein, D. L. Childers, T. L. Gragson, N. B. Grimm, J. M. Grove, S. L. Harlan, J. P. Kaye, A. K. Knapp, G. P. Kofinas, J. J. Magnuson, W. H. McDowell, J. M. Melack, L. A. Ogden, G. P. Robertson, M. D. Smith, and A. C. Whitmer. 2011. An integrated conceptual framework for long-term social-ecological research. Frontiers in Ecology and the Environment 9(6):351-357. http://dx.doi. org/10.1890/100068

Coquil, X., B. Dedieu, and P. Béguin. 2010. How do livestock and crop sciences represent evolutions of farming systems? A review. Pages 1255-1266 in I. Darnhofer and M. Grötzer, editors. Proceedings of the 9th European IFSA Symposium. Universität für Bodenkultur, Vienna, Austria. [online] URL: http://ifsa.boku. ac.at/cms/fileadmin/Proceeding2010/2010 WS2.5 Coquil etal.pdf

Cruz, P., M. Duru, O. Therond, J. P. Theau, C. Ducourtieux, C. Jouany, R. Al Haj Khaled, and P. Ansquer. 2002. Une nouvelle approche pour caractériser les prairies naturelles et leur valeur d'usage. Fourrages 172:335-354.

Cumming, G. S., G. Barnes, S. Perz, M. Schmink, K. E. Sieving, J. Southworth, M. Binford, R. D. Holt, C. Stickler, and T. Van Holt. 2005. An exploratory framework for the empirical measurement of resilience. Ecosystems 8(8):975-987. http://dx. doi.org/10.1007/s10021-005-0129-Z

Daget, P., and J. Poissonet. 1971. Une méthode d'analyse phytologique des prairies: critères d'application. Annales Agronomiques 22(1):5-41.

Daget, P., and J. Poissonet. 1972. Un procédé d'estimation de la valeur pastorale des pâturages. Fourrages 49:31-39.

Darnhofer, I. 2010. Strategies of family farms to strengthen their resilience. Environmental Policy and Governance 20(4):212-222. http://dx.doi.org/10.1002/eet.547 
Darnhofer, I. 2014. Resilience and why it matters for farm management. European Review of Agricultural Economics 41 (3):461-484. http://dx.doi.org/10.1093/erae/jbu012

Darnhofer, I., S. Bellon, B. Dedieu, and R. Milestad. $2010 a$. Adaptiveness to enhance the sustainability of farming systems: a review. Agronomy for Sustainable Development 30(3):545-555. https://doi.org/10.1051/agro/2009053

Darnhofer, I., J. Fairweather, and H. Moller. 2010b. Assessing a farm's sustainability: insights from resilience thinking. International Journal of Agricultural Sustainability 8(3):186-198.

Darnhofer, I., M. Schermer, M. Steinbacher, M. Gabillet, and K. Daugstad. 2017. Preserving permanent mountain grasslands in Western Europe: Why are promising approaches not implemented more widely? Land use Policy 68:306-315. https://doi.org/10.1016/ j.landusepol.2017.08.005

De La Torre, A., E. Recoules, F. Blanc, I. Ortigues-Marty, P. D'Hour, and J. Agabriel. 2015. Changes in calculated residual energy in variable nutritional environments: an indirect approach to apprehend suckling beef cows' robustness. Livestock Science 176:75-84. http://dx.doi.org/10.1016/j.livsci.2015.03.008

Dedieu, B., P. Faverdin, J. Y. Dourmad, and A. Gibon. 2008. Système d'élevage, un concept pour raisonner les transformations de l'élevage. INRA Productions Animales 21(1):45-58.

Dedieu, B., A. Gibon, A. Ickowicz, and J.-F. Tourrand. 2010. Transformations des élevages extensifs et des territoires ruraux. Cahiers Agricultures 19(2):81-83.

Dedieu, B., and S. Ingrand. 2010. Incertitude et adaptation: cadres théoriques et application à l'analyse de la dynamique des systèmes d'élevage. INRA Productions Animales 23(1):81-90.

Dobremez, L., B. Nettier, J.-P. Legeard, B. Caraguel, L. Garde, S. Vieux, S. Lavorel, and M. Della-Vedova. 2014. Sentinel alpine pastures: an original programme for a new form of shared governance to face the climate challenge. Journal of Alpine Research | Revue de géographie alpine 102:2. http://dx.doi. org/10.4000/rga.2455

Domptail, S., M. H. Easdale, and Yuerlita. 2013. Managing socioecological systems to achieve sustainability: a study of resilience and robustness. Environmental Policy and Governance 23(1):30-45. http://dx.doi.org/10.1002/eet.1604

Engler, R., C. F. Randin, W. Thuiller, S. Dullinger, N. E. Zimmermann, M. B. Araújo, P. B. Pearman, G. Le Lay, C. Piedallu, C. H. Albert, P. Choler, G. Coldea, X. De Lamo, T. Dirnböck, J.-C. Gégout, D. Gómez-García, J.-A. Grytnes, E. Heegaard, F. Høistad, D. Nogués-Bravo, S. Normand, M. Puşcaş, M.-T. Sebastià, A. Stanisci, J.-P. Theurillat, M. R. Trivedi, P. Vittoz, and A. Guisan. 2011. 21st century climate change threatens mountain flora unequally across Europe. Global Change Biology 17(7):2330-2341. http://dx.doi.org/10.1111/j.1365-2486.2010.02393. $\underline{x}$

Etienne, M., editor. 2014. Companion modelling: a participatory approach to support sustainable development. Springer, Amsterdam, the Netherlands. http://dx.doi.org/10.1007/978-94-$\underline{017-8557-0}$
Eychenne, C. 2008. Les éleveurs et l'estive: pour une approche compréhensive des pratiques pastorales. Natures Sciences Sociétés 16(2):131-138. http://dx.doi.org/10.1051/nss:2008033

Eychenne, C., and L. Lazaro. 2014. Summer pastures: between "commons" and "public goods": representations of pastoral areas and forms of government intervention. Journal of Alpine Research | Revue de géographie alpine 102:2. http://dx.doi. org/10.4000/rga.2303

Farrié, B., M. Jouven, F. Launay, J.-C. Moreau, C.-H. Moulin, M. Piquet, M. Taverne, E. Tchakérian, V. Thénard, and G. Martin. 2015. Rangeland rummy - a board game to support adaptive management of rangeland-based livestock systems. Journal of Environmental Management 147:236-245. http://dx.doi.org/10.1016/ j.jenvman.2014.08.018

Flamant, J. C., C. Béranger, and A. Gibon. 1999. Animal production and land use sustainability: an approach from the farm diversity at territory level. Livestock Production Science 61 (2-3):275-286. http://dx.doi.org/10.1016/S0301-6226(99)00077-9

Folke, C., S. Carpenter, B. Walker, M. Scheffer, T. Elmqvist, L. Gunderson, and C. S. Holling. 2004. Regime shifts, resilience, and biodiversity in ecosystem management. Annual Review of Ecology, Evolution, and Systematics 35:557-581. http://dx.doi. org/10.1146/annurev.ecolsys.35.021103.105711

Gibon, A., A. R. Sibbald, J. C. Flamant, P. Lhoste, R. Revilla, R. Rubino, and J. T. Sørensen. 1999. Livestock farming systems research in Europe and its potential contribution for managing towards sustainability in livestock farming. Livestock Production Science 61(2-3):121-137. http://dx.doi.org/10.1016/S0301-6226 (99)00062-7

Gottfried, M., H. Pauli, A. Futschik, M. Akhalkatsi, P. Barančok, J. L. Benito Alonso, G. Coldea, J. Dick, B. Erschbamer, M. R. Fernández Calzado, G. Kazakis, J. Krajči, P. Larsson, M. Mallaun, O. Michelsen, D. Moiseev, P. Moiseev, U. Molau, A. Merzouki, L. Nagy, G. Nakhutsrishvili, B. Pedersen, G. Pelino, M. Puscas, G. Rossi, A. Stanisci, J.-P. Theurillat, M. Tomaselli, L. Villar, P. Vittoz, I. Vogiatzakis, and G. Grabherr. 2012. Continent-wide response of mountain vegetation to climate change. Nature Climate Change 2:111-115. http://dx.doi. org/10.1038/nclimate1329

Gouttenoire, L., S. Cournut, and S. Ingrand. 2010. Building causal maps of livestock farming systems using a participatory method with dairy farmers. Pages 444-452 in I. Darnhofer and M. Grötzer, editors. Proceedings of the 9th European IFSA Symposium. Universität für Bodenkultur, Vienna, Austria. [online] URL: http://ifsa.boku.ac.at/cms/fileadmin/

Proceeding2010/2010 WS1.4 Gouttenoire.pdf

Gross, H., N. Girard, and D. Magda. 2011. Analyzing theory and use of management tools for sustainable agri-environmental livestock practices: the case of the pastoral value in the French Pyrenees mountains. Journal of Sustainable Agriculture 35 (5):550-573. http://dx.doi.org/10.1080/10440046.2011.579840

Guérin, G., C. Agreil, G. Aussibal, L. Garde, D. Gautier, and M. Meuret. 2007. Qualifier les surfaces pastorales pour combiner le renouvellement des ressources alimentaires et la maîtrise des couverts végétaux. Acquis, enjeux et questions actuelles. Pages 
145-152 in Rencontres autour des Recherches sur les Ruminants. INRA-Institut de l'Elevage, Paris, France.

Guéringer, A., H. Rapey, M. Houdart, G. Bigot, E. Josien, and F. Landré. 2009. Adaptability through spatial management: a case study of livestock farms in the Massif Central, France. Outlook on Agriculture 38(2):111-118. http://dx.doi.org/10.5367/0000000$\underline{09788632430}$

Gunderson, L. H., and C. S. Holling. 2002. Panarchy: understanding transformations in human and natural systems. Island Press, Washington, D.C., USA.

Hagmann, J., and E. Chuma. 2002. Enhancing the adaptive capacity of the resource users in natural resource management. Agricultural Systems 73(1):23-39. http://dx.doi.org/10.1016/ $\underline{\text { S0308-521X(01)00098-1 }}$

Intergovernmental Panel on Climate Change (IPCC). 2012. Managing the risks of extreme events and disasters to advance climate change adaptation. A Special Report of Working Groups I and II of the Intergovernmental Panel on Climate Change. C. B. Field, V. Barros, T. F. Stocker, D. Qin, D. J. Dokken, K. L. Ebi, M. D. Mastrandrea, K. J. Mach, G.-K. Plattner, S. K. Allen, M. Tignor, and P. M. Midgley, editors. Cambridge University Press, Cambridge, UK. [online] URL: https://wg1.ipcc.ch/srex/

Intergovernmental Panel on Climate Change (IPCC). 2013. Climate change 2013: the physical science basis. Working Group I contribution to the Fifth Assessment Report of the Intergovernmental Panel on Climate Change. T. F. Stocker, D. Qin, G.-K. Plattner, M. M. B. Tignor, S. K. Allen, J. Boschung, A. Nauels, Y. Xia, V. Bex, and P. M. Midgley, editors. Cambridge University Press, Cambridge, UK. [online] URL: http://www. ipcc.ch/report/ar5/wg1/

Intergovernmental Panel on Climate Change (IPCC). 2014. Climate change 2014: impacts, adaptation, and vulnerability. Working Group II contribution to the Fifth Assessment Report of the Intergovernmental Panel on Climate Change. V. R. Barros, C. B. Field, D. J. Dokken, M. D. Mastrandrea, K. J. Mach, T. E. Bilir, M. Chatterjee, K. L. Ebi, Y. Otsuki Estrada, R. C. Genova, B. Girma, E. S. Kissel, A. N. Levy, S. MacCracken, P. R. Mastrandrea, L. L. White, editors. Cambridge University Press, Cambridge, UK. [online] URL: http://www.ipcc.ch/report/ar5/ $\underline{\text { wg2l }}$

Jacquot, A.-L. M. 2012. Dynamilk: un simulateur pour étudier les compromis entre performances animales, utilisation des ressources herbagères et recherche d'autonomie alimentaire dans les systèmes bovins laitiers de montagne. Dissertation. Université Blaise Pascal, Clermont-Ferrand, France. [online] URL: https://tel.archivesouvertes.fr/tel-00825677/document

Jacquot, A. L., F. Blanc, C. Lacour, R. Baumont, G. Brunschwig, and C. Agabriel. 2010. Relations entre période de vêlages et conduite des surfaces fourragères: étude dans des élevages laitiers herbagers du Puy-de-Dôme. Page 61 in Rencontres autour des Recherches sur les Ruminants. INRA et Institut de l'Elevage, Paris, France.

Jonas, T., C. Rixen, M. Sturm, and V. Stoeckli. 2008. How alpine plant growth is linked to snow cover and climate variability. Journal of Geophysical Research: Biogeosciences 113(G3): G03013. http://dx.doi.org/10.1029/2007JG000680
Jouglet, J.-P. 1999. Les végétations des alpages des Alpes françaises du Sud: guide technique pour la reconnaissance et la gestion des milieux pâturés d'altitude. Quae, Versailles, France.

Lynam, T., F. Bousquet, C. Le Page, P. d'Aquino, O. Barreteau, F. C. Chinembiri, and B. Mombeshora. 2002. Adapting science to adaptive managers: spidergrams, belief models, and multiagent systems modeling. Ecology and Society 5(2):24. [online] URL: http://www.consecol.org/vol5/iss2/art24/

Lynam, T., W. de Jong, D. Sheil, T. Kusumanto, and K. Evans. 2007. A review of tools for incorporating community knowledge, preferences, and values into decision making in natural resources management. Ecology and Society 12(1):5. http://dx.doi. org/10.5751/ES-01987-120105

Martin, G., L. Hossard, J. P. Theau, O. Therond, E. Josien, P. Cruz, J. P. Rellier, R. Martin-Clouaire, and M. Duru. 2009. Characterizing potential flexibility in grassland use. Application to the French Aubrac area. Agronomy for Sustainable Development 29(2):381-389. https://doi.org/10.1051/agro:2008063

Mathevet, R., C. Le Page, M. Etienne, G. Lefebvre, B. Poulin, G. Gigot, S. Proréol, and A. Mauchamp. 2007. BUTORSTAR: a role-playing game for collective awareness of wise reedbed use. Simulation and Gaming 38(2):233-262. http://dx.doi. org/10.1177/1046878107300665

McIntyre, S., and S. Lavorel. 2007. A conceptual model of land use effects on the structure and function of herbaceous vegetation. Agriculture, Ecosystems and Environment 119(1-2):11-21. http:// dx.doi.org/10.1016/j.agee.2006.06.013

Meuret, M., and F. Provenza, editors. 2014. The art and science of shepherding: tapping the wisdom of French herders. Acres USA, Austin, Texas, USA.

Milestad, R., and I. Darnhofer. 2003. Building farm resilience: the prospects and challenges of organic farming. Journal of Sustainable Agriculture 22(3):81-97. http://dx.doi.org/10.1300/ $\underline{\mathrm{J} 064 \mathrm{v} 22 \mathrm{n} 03 \quad 09}$

Miller, F., H. Osbahr, E. Boyd, F. Thomalla, S. Bharwani, G. Ziervogel, B. Walker, J. Birkmann, S. van der Leeuw, J. Rockström, J. Hinkel, T. Downing, C. Folke, and D. Nelson. 2010. Resilience and vulnerability: complementary or conflicting concepts? Ecology and Society 15(3):11. [online] URL: http://www. ecologyandsociety.org/vol15/iss3/art11/

Mottet, A., S. Ladet, N. Coqué, and A. Gibon. 2006. Agricultural land-use change and its drivers in mountain landscapes: a case study in the Pyrenees. Agriculture, Ecosystems and Environment 114(2-4):296-310. http://dx.doi.org/10.1016/j.agee.2005.11.017

Moulin, C., N. Girard, and B. Dedieu. 2001. L'apport de l'analyse fonctionnelle des systèmes d'alimentation. Fourrages 167:337-363.

Murray-Rust, D., C. Brown, J. van Vliet, S. J. Alam, D. T. Robinson, P. H. Verburg, and M. Rounsevell. 2014. Combining agent functional types, capitals and services to model land use dynamics. Environmental Modelling and Software 59:187-201. http://dx.doi.org/10.1016/j.envsoft.2014.05.019

Nettier, B., L. Dobremez, and G. Brunschwig. 2015. Prendre en compte les interactions entre alpages et exploitations dans les systèmes agropastoraux: une revue bibliographique. INRA Productions Animales 28(4):329-340. 
Nettier, B., L. Dobremez, J.-L. Coussy, and T. Romagny. 2010. Attitudes of livestock farmers and sensitivity of livestock farming systems to drought conditions in the French Alps. Journal of Alpine Research | Revue de géographie alpine 98:4. http://dx.doi. org/10.4000/rga.1307

Nettier, B., L. Dobremez, M. Talichet, T. Romagny, and V. Le Pottier. 2011. Managing the summer alpine pastures in a context of recurrent droughts. Pages 61-63 in E. M. Pötsch, B. Krautzer, and A. Hopkins, editors. Grassland farming and land management systems in mountainous regions: proceedings of the 16th symposium of the European Grassland Federation. Raumberg-Gumpenstein, Irdning, Austria. [online] URL: http://www.europeangrassland. org/fileadmin/media/EGF2011.pdf

Ollion, E. 2015. Evaluation de la robustesse des vaches laitières: entre aptitudes biologiques des animaux et stratégies de conduite des éleveurs. Dissertation. Université Blaise Pascal, ClermontFerrand, France. [online] URL: https://tel.archives-ouvertes.fr/ tel-01312209/document

Oteros-Rozas, E., R. Ontillera-Sánchez, P. Sanosa, E. GómezBaggethun, V. Reyes-García, and J. A. González. 2013. Traditional ecological knowledge among transhumant pastoralists in Mediterranean Spain. Ecology and Society 18(3):33. http://dx. doi.org/10.5751/ES-05597-180333

Perrings, C. 2006. Resilience and sustainable development. Environment and Development Economics 11(4):417-427. http:// dx.doi.org/10.1017/S1355770X06003020

Quinlan, A. E., M. Berbés-Blázquez, L. J. Haider, and G. D. Peterson. 2016. Measuring and assessing resilience: broadening understanding through multiple disciplinary perspectives. Journal of Applied Ecology 53:677-687. http://dx.doi.org/10.1111/1365-2664.12550

Reed, M. S. 2008. Stakeholder participation for environmental management: a literature review. Biological Conservation 141 (10):2417-2431. http://dx.doi.org/10.1016/j.biocon.2008.07.014

Reid, R. S., M. E. Fernández-Giménez, and K. A. Galvin. 2014. Dynamics and resilience of rangelands and pastoral peoples around the globe. Annual Review of Environment and Resources 39:217-242. http://dx.doi.org/10.1146/annurev-environ-020713-163329

Resilience Alliance. 2007. Assessing and managing resilience in social-ecological systems: a practitioners workbook. Version 1.0. Resilience Alliance. [online] URL: http://www.sustentabilidad. uai.edu.ar/pdf/cs/practitioner workbook 1.pdf

Resilience Alliance. 2010. Assessing resilience in social-ecological systems: workbook for practitioners. Version 2.0. Resilience Alliance. [online] URL: http://www.reefresilience.org/pdf/ ResilienceAssessment2.pdf

Rigolot, C., S. Roturier, B. Dedieu, and S. Ingrand. 2014. Climate variability drives livestock farmers to modify their use of collective summer mountain pastures. Agronomy for Sustainable Development 34(4):899-907. http://dx.doi.org/10.1007/s13593-014-0224-7

Rissman, A. R., and S. Gillon. 2017. Where are ecology and biodiversity in social-ecological systems research? A review of research methods and applied recommendations. Conservation Letters 10(1):86-93. http://dx.doi.org/10.1111/conl.12250
Roling, N. G., and M. A. E. Wagemakers. 2000. Facilitating sustainable agriculture: participatory learning and adaptive management in times of environmental uncertainty. Cambridge University Press, Cambridge, UK.

Savini, I., E. Landais, P. Thinon, and J. P. Deffontaines. 1995. L'organisation de l'espace pastoral: des concepts et des représentations construits à dire d'experts dans une perspective de modélisation. Pages 137-160 in E. Landais and G. Balent, editors. Pratiques d'elevage extensif: identifier, modéliser, évaluer. INRA, Paris, France.

Savini, I., E. Landais, P. Thinon, and J.-P. Deffontaines. 2010. Des pratiques d'un berger expérimenté à la construction d'outils d'aide à la gestion d'alpages. Pages 81-100 in M. Meuret, editor. Un savoir-faire de bergers. Quae, Dijon-Versailles, France. http:// dx.doi.org/10.3917/quae.meure.2010.01.0081

Schär, C., P. L. Vidale, D. Lüthi, C. Frei, C. Häberli, M. A. Liniger, and C. Appenzeller. 2004. The role of increasing temperature variability in European summer heatwaves. Nature 427 (6972):332-336. http://dx.doi.org/10.1038/nature02300

Schermer, M., I. Darnhofer, K. Daugstad, M. Gabillet, S. Lavorel, and M. Steinbacher. 2016. Institutional impacts on the resilience of mountain grasslands: an analysis based on three European case studies. Land Use Policy 52:382-391. http://dx.doi. org/10.1016/j.landusepol.2015.12.009

Scherrer, D., and C. Körner. 2010. Infra-red thermometry of alpine landscapes challenges climatic warming projections. Global Change Biology 16(9):2602-2613. http://dx.doi.org/10.1111/ j.1365-2486.2009.02122.X

Smit, B., and J. Wandel. 2006. Adaptation, adaptive capacity and vulnerability. Global Environmental Change 16(3):282-292. http:// dx.doi.org/10.1016/j.gloenvcha.2006.03.008

Soane, I. D., R. Scolozzi, A. Gretter, and K. Hubacek. 2012. Exploring panarchy in alpine grasslands: an application of adaptive cycle concepts to the conservation of a cultural landscape. Ecology and Society 17(3):18. http://dx.doi. org/10.5751/ES-05085-170318

Tengö, M., and K. Belfrage. 2004. Local management practices for dealing with change and uncertainty: a cross-scale comparison of cases in Sweden and Tanzania. Ecology and Society 9(3):4. http://dx.doi.org/10.5751/ES-00672-090304

Tittonell, P. 2014. Livelihood strategies, resilience and transformability in African agroecosystems. Agricultural Systems 126:3-14. http://dx.doi.org/10.1016/j.agsy.2013.10.010

van Kerkhoff, L., and L. Lebel. 2006. Linking knowledge and action for sustainable development. Annual Review of Environment and Resources 31(1):445-477. http://dx.doi. org/10.1146/annurev.energy.31.102405.170850

Verfaillie, D., M. Déqué, S. Morin, and M. Lafaysse. 2016. The downscaling and adjustment method ADAMONT v1.0 for climate projections in mountainous regions applicable to energy balance land surface models. Geoscientific Model Development Discussion 2016:1-53. 
Voinov, A., and F. Bousquet. 2010. Modelling with stakeholders. Environmental Modelling and Software 25(11):1268-1281. http:// dx.doi.org/10.1016/j.envsoft.2010.03.007

Walker, B. H., N. Abel, J. M. Anderies, and P. Ryan. 2009. Resilience, adaptability, and transformability in the GoulburnBroken catchment, Australia. Ecology and Society 14(1):12. http://dx.doi.org/10.5751/ES-02824-140112

Walker, B., S. Carpenter, J. Anderies, N. Abel, G. S. Cumming, M. Janssen, L. Lebel, J. Norberg, G. D. Peterson, and R. Pritchard. 2002. Resilience management in social-ecological systems: a working hypothesis for a participatory approach. Ecology and Society 6(1):14. http://dx.doi.org/10.5751/ES-00356-060114

Walker, B., L. Gunderson, A. Kinzig, C. Folke, S. Carpenter, and L. Schultz. 2006. A handful of heuristics and some propositions for understanding resilience in social-ecological systems. Ecology and Society 11(1):13. http://dx.doi.org/10.5751/ES-01530-110113

Walker, B., C. S. Holling, S. R. Carpenter, and A. Kinzig. 2004. Resilience, adaptability and transformability in social-ecological systems. Ecology and Society 9(2):5. http://dx.doi.org/10.5751/ ES-00650-090205

Walker, B., and D. Salt. 2006. Resilience thinking: sustaining ecosystems and people in a changing world. Island Press, Washington, D.C., USA.

Walker, B., and D. Salt. 2012. Resilience practice: building capacity to absorb disturbance and maintain function. Island Press, Washington, D.C., USA. http://dx.doi.org/10.5822/978-1-61091-231-0

Walsh, K., M. Court-Picon, J.-L. de Beaulieu, F. Guiter, F. Mocci, S. Richer, R. Sinet, B. Talon, and S. Tzortzis. 2014. A historical ecology of the Ecrins (southern French Alps): archaeology and palaeoecology of the Mesolithic to the Medieval period. Quaternary International 353:52-73. http://dx.doi.org/10.1016/j. quaint.2013.08.060

Westoby, M., B. Walker, and I. Noy-Meir. 1989. Opportunistic management for rangelands not at equilibrium. Journal of Range Management 42(4):266-274. http://dx.doi.org/10.2307/3899492 
Appendix 1: Overview of the different elements of the conceptual model of mountain summer pasture functioning

\section{Overall architecture of the model}
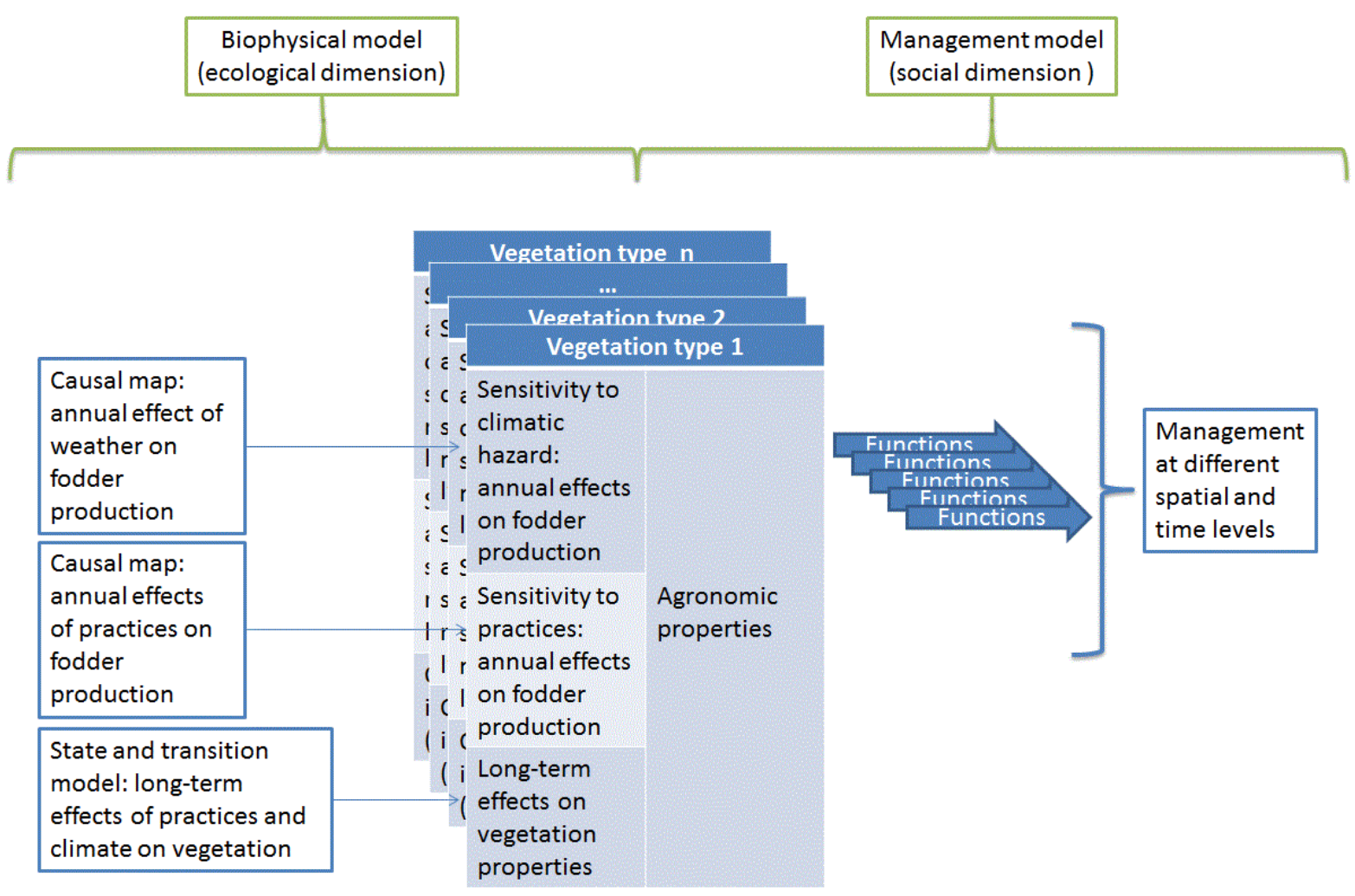
Causal maps detailing the causal links between weather parameters

and vegetation growth and phenology

\section{Key}

Weather parameter

Subalpine stage vegetation parameter

Alpine stage vegetation parameter

Positive effect of one parameter on another

Negative effect of one parameter on another

Particularly important effect

Effect of negligible importance 


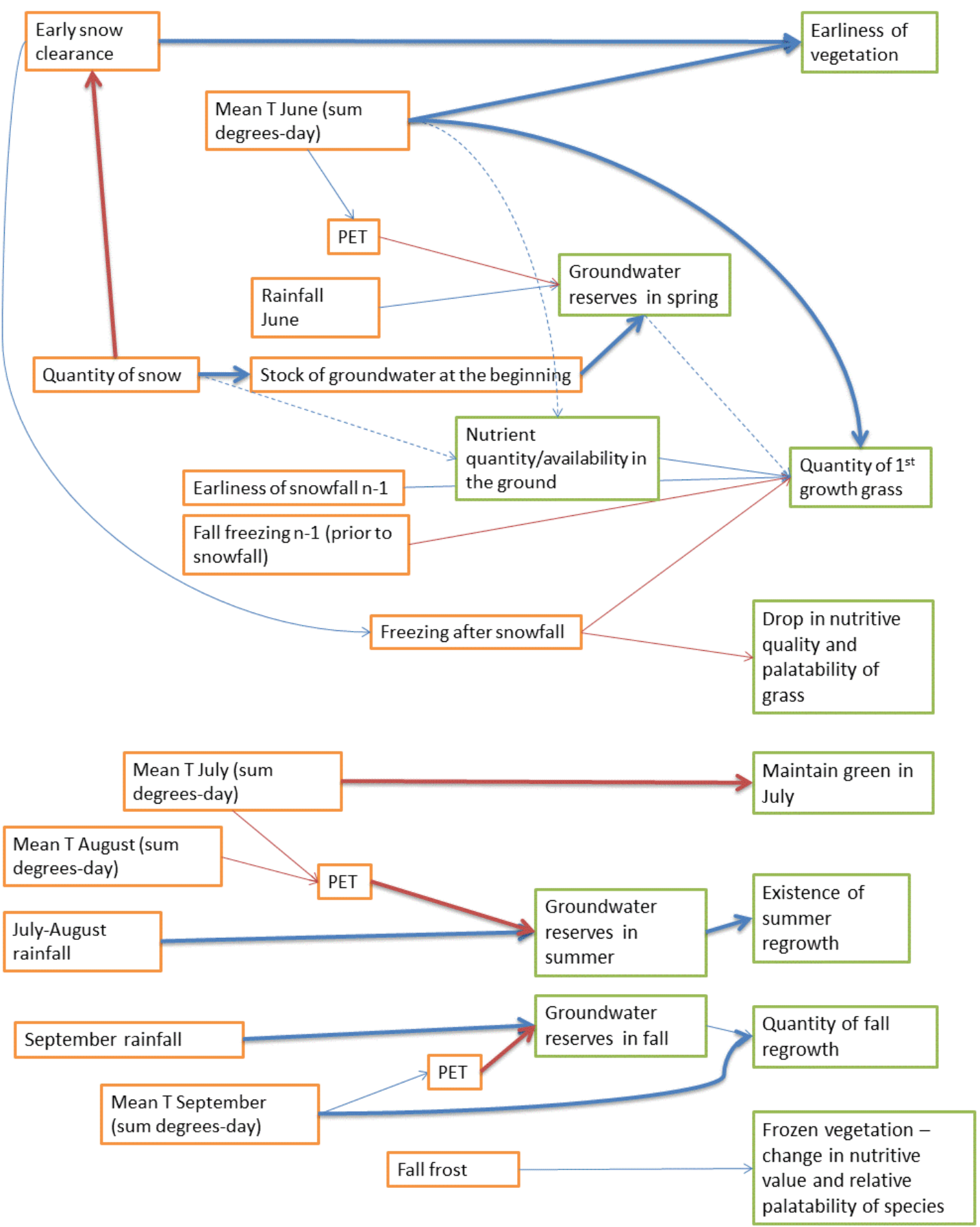

Subalpine stage 

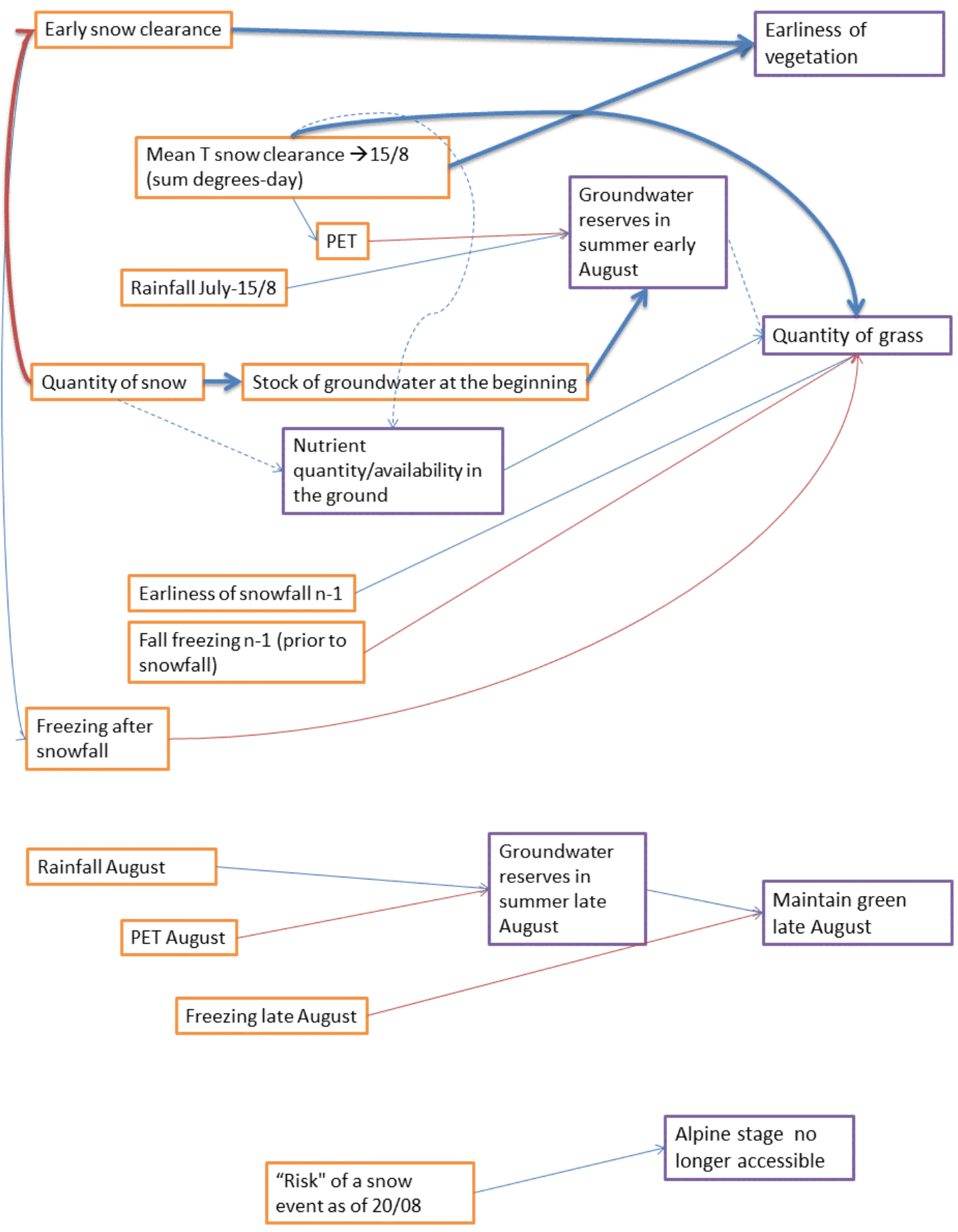

\section{Alpine stage}


Causal map, detailing the causal links between pastoral practices

and vegetation growth and phenology

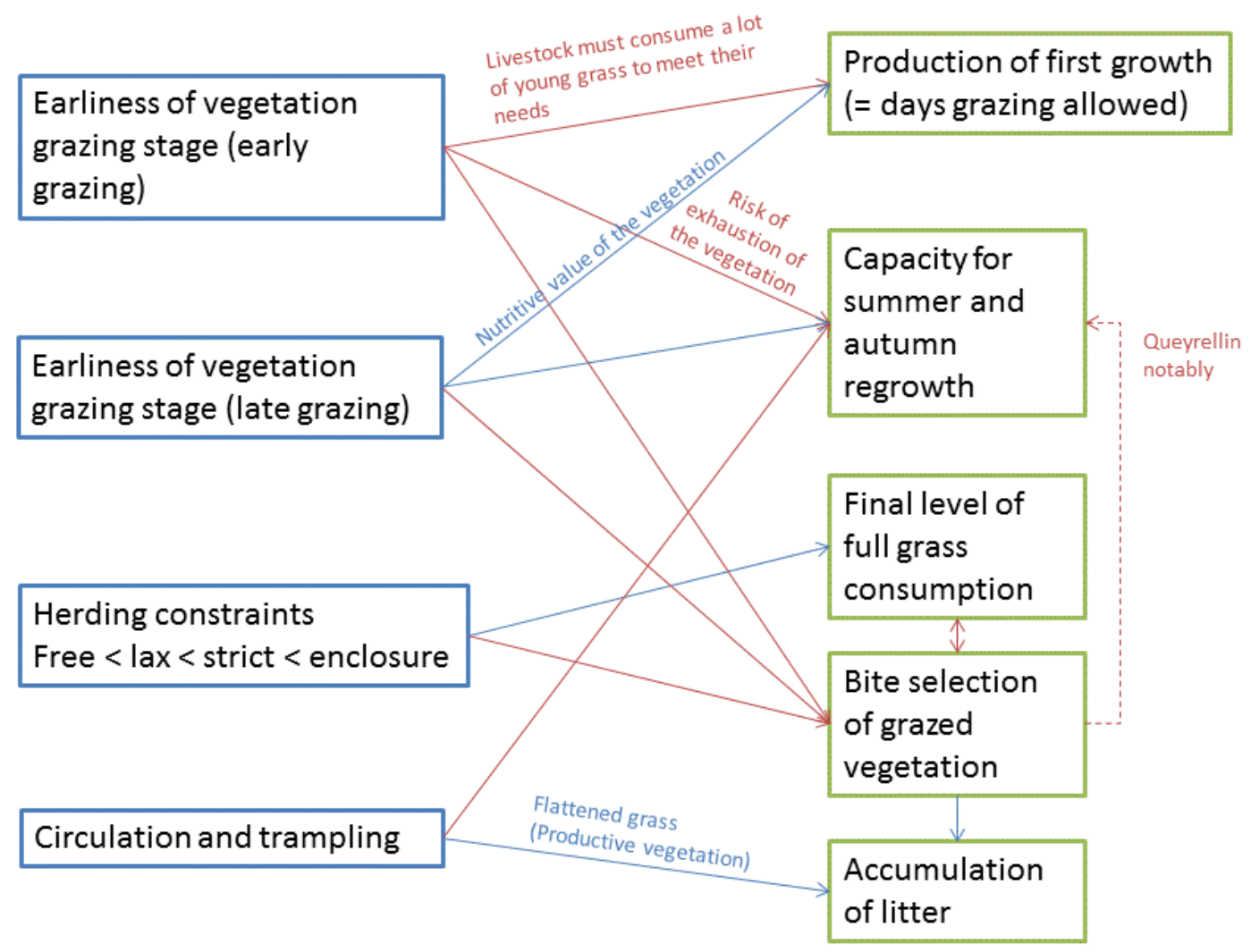



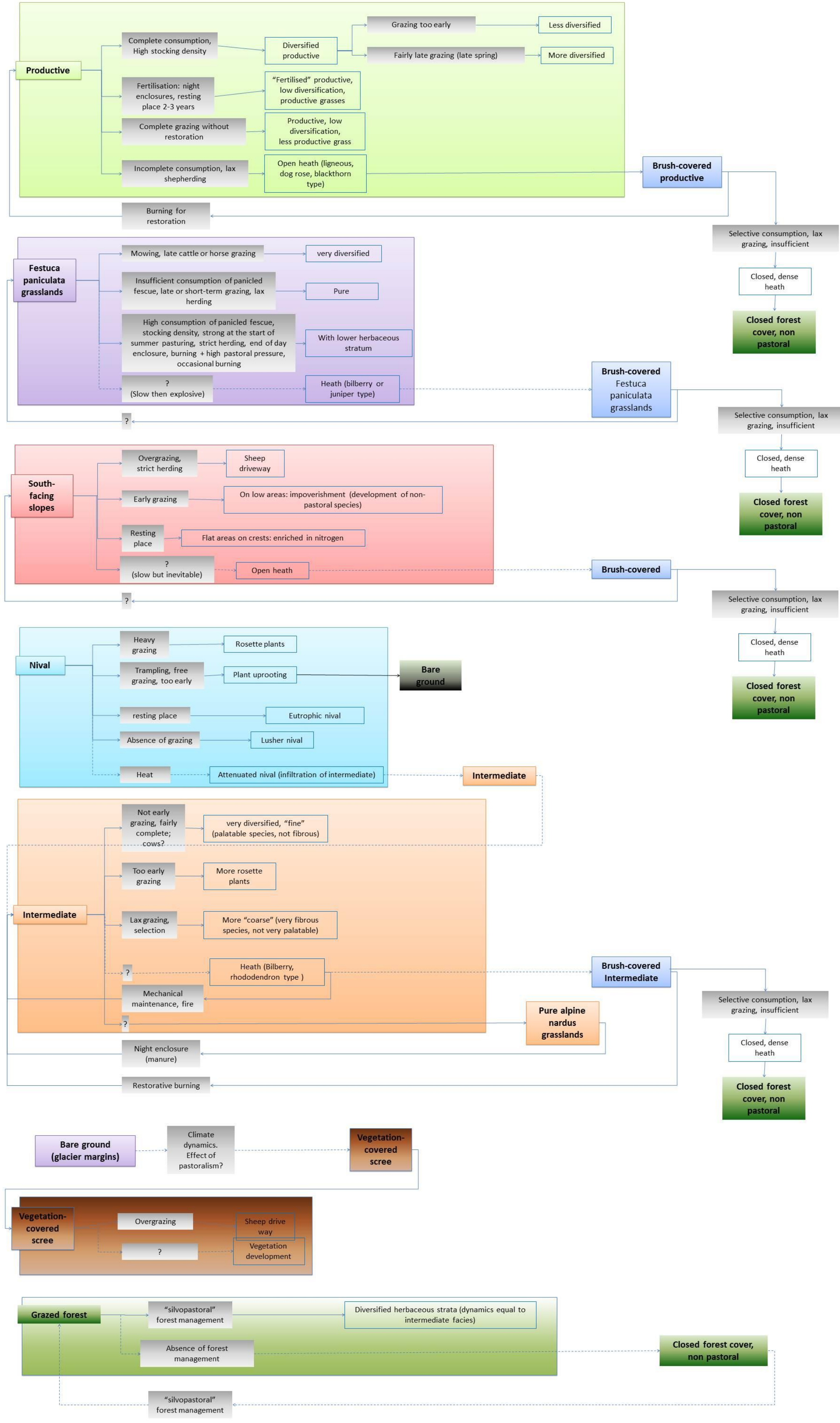

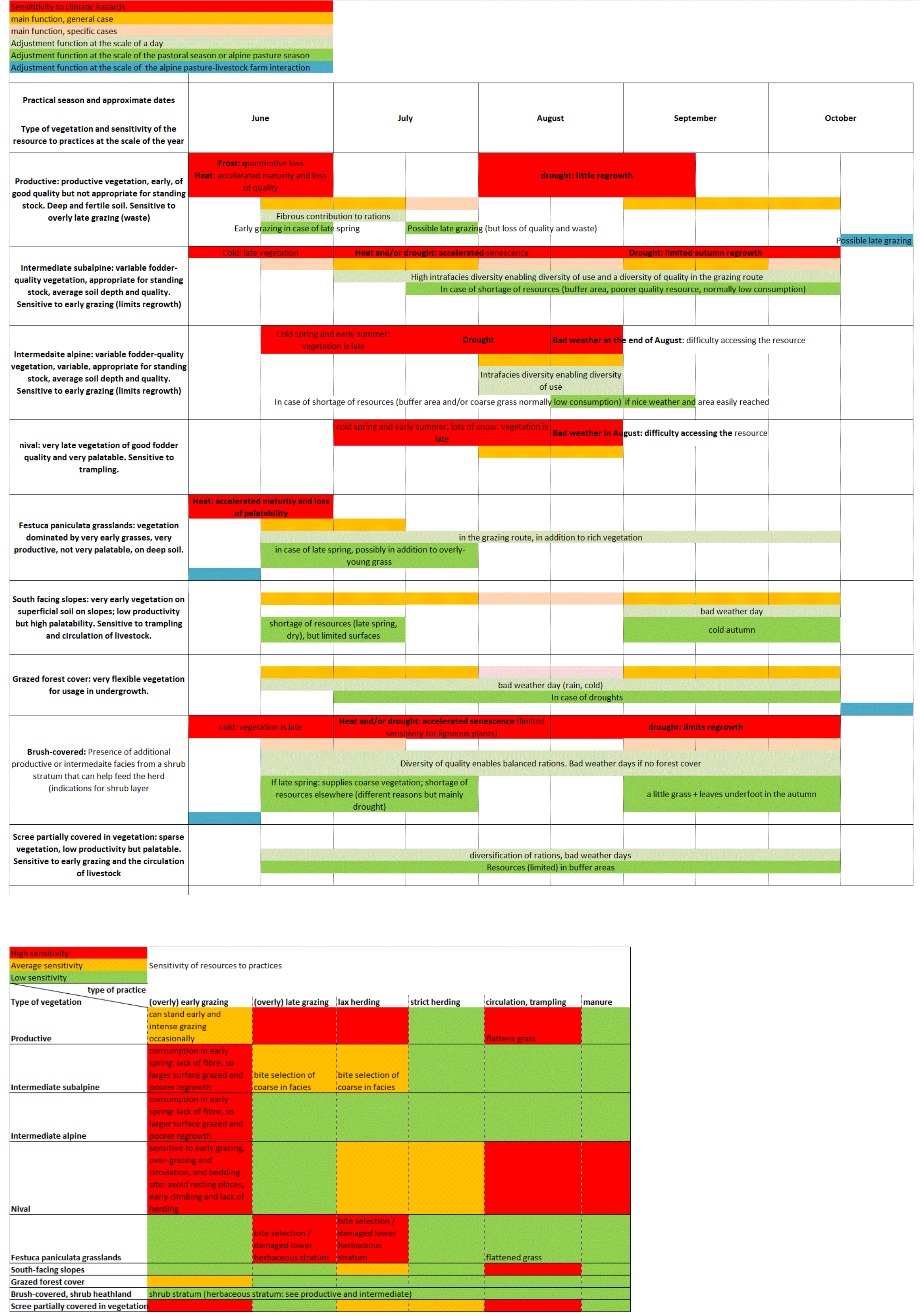


\section{Management model}

\begin{tabular}{|c|c|c|c|}
\hline Time scale & Spatial scale & System managers & General management objectives \\
\hline Day & $\begin{array}{l}\text { Grazing route (route followed by the herd } \\
\text { during the course of the day). It is made } \\
\text { up of a series of sectors, which are } \\
\text { physical units whose characteristics } \\
\text { determine a specific spatial and feeding } \\
\text { behaviour for the herd. }\end{array}$ & $\begin{array}{l}\text { Self-sufficient herder(s) up on } \\
\text { the summer pasture (this } \\
\text { scale has no meaning for } \\
\text { summer pastures without } \\
\text { permanent shepherding). }\end{array}$ & $\begin{array}{l}\text { Depending on daily events (weather, availability of the } \\
\text { herder), composing the daily ration of the herd via a } \\
\text { succession of different vegetation types while adapting to } \\
\text { the herd's behaviour (based on knowledge of the summer } \\
\text { pasture and vegetation) and influencing its feeding } \\
\text { behaviour (more or less selection among the plants grazed) } \\
\text { through different types of herding methods. }\end{array}$ \\
\hline $\begin{array}{l}\text { Pastoral } \\
\text { season } \\
\text { (duration: } \\
\text { roughly one } \\
\text { month) }\end{array}$ & $\begin{array}{l}\text { Range allotment: all of the sectors grazed } \\
\text { during the same summer period, often } \\
\text { characterized by a single resting spot for } \\
\text { the herd, and defined by the elevation } \\
\text { and/or topographical constraints that limit } \\
\text { movement between allotments. }\end{array}$ & $\begin{array}{l}\text { The herder(s) on the summer } \\
\text { pasture, the livestock } \\
\text { farmer(s) who may } \\
\text { occasionally get involved in } \\
\text { collective tasks or regulate } \\
\text { livestock numbers and needs } \\
\text { (through sorting, bringing part } \\
\text { of the livestock up or down). }\end{array}$ & $\begin{array}{l}\text { Manage the succession of grazing routes, in order to ensure } \\
\text { that resources are sufficient both in terms of quantity and } \\
\text { quality, during the entire season. }\end{array}$ \\
\hline $\begin{array}{l}\text { Summer } \\
\text { pasture season } \\
\text { (duration: } \\
\text { three to four } \\
\text { months) }\end{array}$ & The entire summer pasture. & As above & $\begin{array}{l}\text { To structure the use of different allotments according to } \\
\text { phenology, capacity to remain as standing fodder stocks } \\
\text { and quantity of grass on these allotments. }\end{array}$ \\
\hline Year & $\begin{array}{l}\text { Summer pasture-farm system: summer } \\
\text { pasture(s) and the farm(s) that use them. }\end{array}$ & Farmer(s). & $\begin{array}{l}\text { Choice of number and types of summer pasturing livestock } \\
\text { (dietary needs, tolerance to dietary deficiency), summer } \\
\text { pasturing dates and zootechnical management (presence or } \\
\text { not of sires in the summer pasture, for example). }\end{array}$ \\
\hline Long term & $\begin{array}{l}\text { All of the previously mentioned spatial } \\
\text { scales. }\end{array}$ & $\begin{array}{l}\text { Farmers and herders (the } \\
\text { group of herders and farmers } \\
\text { can change over the years). }\end{array}$ & $\begin{array}{l}\text { To manage the trajectory of the vegetation through } \\
\text { practices and through the configuration (equipment, } \\
\text { parcels) of summer pastures and farms. Decide main } \\
\text { zootechnical objectives for farms (type of production, } \\
\text { numbers, economic model, selection criteria, reproduction } \\
\text { and selling periods, livestock learning, etc.), the associated } \\
\text { technical management elements, and in particular the } \\
\text { functions attributed to summer pastures in this } \\
\text { management system. }\end{array}$ \\
\hline
\end{tabular}

